\title{
The relaxation of $\mathrm{OH}(v=1)$ and $\mathrm{OD}(v=1)$ by $\mathrm{H}_{2} \mathrm{O}$ and $\mathrm{D}_{2} \mathrm{O}$ at temperatures from 251 to $390 \mathrm{~K}$
}

\author{
D. C. McCabe $\dagger^{a b c}$ B. Rajakumar, $\uparrow^{a c}$ P. Marshall, ${ }^{d}$ I. W. M. Smith ${ }^{e}$ and \\ A. R. Ravishankara ${ }^{a b c}$
}

Received 30th June 2006, Accepted 7th August 2006

First published as an Advance Article on the web 7th September 2006

DOI: $10.1039 / \mathrm{b} 609330 b$

\begin{abstract}
We report rate coefficients for the relaxation of $\mathrm{OH}(v=1)$ and $\mathrm{OD}(v=1)$ by $\mathrm{H}_{2} \mathrm{O}$ and $\mathrm{D}_{2} \mathrm{O}$ as a function of temperature between 251 and $390 \mathrm{~K}$. All four rate coefficients exhibit a negative dependence on temperature. In Arrhenius form, the rate coefficients for relaxation (in units of $10^{-12} \mathrm{~cm}^{3}$ molecule $\left.\mathrm{s}^{-1}\right)$ can be expressed as: for $\mathrm{OH}(v=1)+\mathrm{H}_{2} \mathrm{O}$ between 263 and $390 \mathrm{~K}$ : $k=(2.4 \pm 0.9) \exp ((460 \pm 115) / T)$; for $\mathrm{OH}(v=1)+\mathrm{D}_{2} \mathrm{O}$ between 256 and $371 \mathrm{~K}: k=(0.49 \pm$ $0.16) \exp ((610 \pm 90) / T)$; for $\mathrm{OD}(v=1)+\mathrm{H}_{2} \mathrm{O}$ between 251 and $371 \mathrm{~K}: k=(0.92 \pm 0.16)$ $\exp ((485 \pm 48) / T)$; for $\mathrm{OD}(v=1)+\mathrm{D}_{2} \mathrm{O}$ between 253 and $366 \mathrm{~K}: k=(2.57 \pm 0.09) \exp ((342 \pm$ 10)/T). Rate coefficients at $(297 \pm 1 \mathrm{~K})$ are also reported for the relaxation of $\mathrm{OH}(v=2)$ by $\mathrm{D}_{2} \mathrm{O}$ and the relaxation of $\mathrm{OD}(v=2)$ by $\mathrm{H}_{2} \mathrm{O}$ and $\mathrm{D}_{2} \mathrm{O}$. The results are discussed in terms of a mechanism involving the formation of hydrogen-bonded complexes in which intramolecular vibrational energy redistribution can occur at rates competitive with re-dissociation to the initial collision partners in their original vibrational states. New ab initio calculations on the $\mathrm{H}_{2} \mathrm{O}-\mathrm{HO}$ system have been performed which, inter alia, yield vibrational frequencies for all four complexes: $\mathrm{H}_{2} \mathrm{O}-\mathrm{HO}, \mathrm{D}_{2} \mathrm{O}-\mathrm{HO}, \mathrm{H}_{2} \mathrm{O}-\mathrm{DO}$ and $\mathrm{D}_{2} \mathrm{O}-\mathrm{DO}$. These data are then employed, adapting a formalism due to Troe (J. Troe, J. Chem. Phys., 1977, 66, 4758), in order to estimate the rates of intramolecular energy transfer from the $\mathrm{OH}(\mathrm{OD})$ vibration to other modes in the complexes in order to explain the measured relaxation rates - assuming that relaxation proceeds via the hydrogen-bonded complexes.
\end{abstract}

\section{Introduction}

The notion that vibrational energy transfer in molecular collisions is facilitated by the presence of strong attraction between the collision partners is one of long-standing. ${ }^{1}$ The most clear cut examples of this effect are when the collision partners form a chemical bond. Examples include the relaxation of $\mathrm{NO}(v=$ 1) by $\mathrm{O}$ and $\mathrm{Cl}$ atoms, ${ }^{2}$ and of $\mathrm{OH}(v=1), \mathrm{OD}(v=1)$ and $\mathrm{OH}(v>0)$ by $\mathrm{NO}_{2},{ }^{3,4}$ of $\mathrm{OH}(v=1), \mathrm{OD}(v=1)$ by $\mathrm{NO}^{3}$ of $\mathrm{OH}(v=1), \mathrm{OD}(v=1)$ by $\mathrm{CO},{ }^{5}$ and of $\mathrm{OH}(v=1)$ by $\mathrm{SO}_{2}{ }^{6}$ The large magnitude of the rate coefficients for these processes and the similarity of the rate coefficients for the

${ }^{a}$ NOAA Aeronomy Laboratory, 325 Broadway R/AL2, Boulder, Colorado, 80305, USA

${ }^{b}$ Department of Chemistry and Biochemistry, University of Colorado, Boulder, Colorado, 80309, USA

${ }^{c}$ CIRES, University of Colorado, 80309, USA.

E-mail:ravi@al.noaa.gov

${ }^{d}$ Department of Chemistry and Center for Advanced Scientific Computing and Modeling, University of North Texas, PO Box 305070, Denton, Texas, 76203-5070, USA.

E-mail:marshall@unt.edu

${ }^{e}$ The University Chemical Laboratory, Lensfield Road, Cambridge,

UKCB21EW.E-mail: i.w.m.smith@bham.ac.uk or

iwms2@cam.ac.uk

$\dagger$ Present address: Division of Engineering and Applied Sciences, California Institute of Technology, Pasadena, CA 91125, USA.

E-mail: dmcc@caltech.edu.

$\ddagger$ Present address: Department of Chemistry, Indian Institute of

Technology, Madras 600 036, India. E-mail: rajakumar@iitm.ac.in. relaxation of $\mathrm{OH}(v=1)$ and $\mathrm{OD}(v=1)$ by the same species are rather clear indications that relaxation occurs via complexforming collisions, since the large difference in the vibrational transition energies in $\mathrm{OH}$ and $\mathrm{OD}$ will dramatically change the probability of vibration-to-vibration (V-V) energy exchange. ${ }^{1}$ In these instances of strong intermolecular forces, it appears that intramolecular vibrational energy redistribution (IVR) in the initially formed complex is rapid relative to re-dissociation to the collision partners in their original vibrational states, so that the rate constant for relaxation corresponds to that for initial association of the two species. Such measurements then provide an estimate of the rate coefficient for the association reaction of the same two species in the limit of high pressure. ${ }^{7}$ It is anticipated that the rate constants for both these processes (relaxation and high pressure association) will show a negative, but only a mild negative, dependence on temperature.

The role in vibrational energy transfer of molecular attractions of intermediate strength, specifically those arising from hydrogen bonds, has long been debated. In particular, such forces were invoked in the 1970s to explain the rapid rates observed for the vibrational relaxation of $\operatorname{HF}(v=1)$ both in $\mathrm{HF}-\mathrm{HF}$ collisions ${ }^{8,9}$ and in collisions with $\mathrm{H}_{2} \mathrm{O} .{ }^{86,9-11}$ In such cases, it is less likely that IVR in any complex that is formed will occur faster than re-dissociation to the collision partners in their original vibrational states. Consequently, the mechanism for vibrational relaxation must take account of the competition between IVR in the complex and its re-dissociation without 
Table 1 Predicted dissociation energies $\left(D_{0} / \mathrm{kJ} \mathrm{mol}^{-1}\right)$ and bonding enthalpies $\left(\Delta_{\mathrm{r}} H^{0}{ }_{298} / \mathrm{kJ} \mathrm{mol}^{-1}\right)$ of OH- $\mathrm{H}_{2} \mathrm{O}$ complexes

\begin{tabular}{|c|c|c|c|c|c|c|}
\hline \multicolumn{2}{|l|}{$\mathrm{H}_{2} \mathrm{O}-\mathrm{HO}^{2} A^{\prime}$} & \multicolumn{2}{|l|}{$\mathrm{H}_{2} \mathrm{O}-\mathrm{HO}^{2} A^{\prime \prime}$} & \multicolumn{2}{|c|}{$\underline{\mathrm{HOH}-\mathrm{OH}^{2} A^{\prime \prime}}$} & \multirow[b]{2}{*}{ Ref. } \\
\hline$D_{0} / \mathrm{kJ} \mathrm{mol}^{-1}$ & $\Delta_{\mathrm{r}} H_{298}^{0} / \mathrm{kJ} \mathrm{mol}^{-1}$ & $D_{0} / \mathrm{kJ} \mathrm{mol}^{-1}$ & $\Delta_{\mathrm{r}} H_{298}^{0} / \mathrm{kJ} \mathrm{mol}^{-1}$ & $D_{0} / \mathrm{kJ} \mathrm{mol}^{-1}$ & $\Delta_{\mathrm{r}} H_{298}^{0} / \mathrm{kJ} \mathrm{mol}^{-1}$ & \\
\hline $\begin{array}{l}15.7^{a} \\
21.3-23.8\end{array}$ & $\begin{array}{l}-(17.2-18.0) \\
-9.9^{b c}\end{array}$ & $13.9^{a}$ & $-6.9^{b c}$ & $9.0^{a}$ & $\begin{array}{l}-(8.8-9.6) \\
-4.7^{b c} \\
-8.8\end{array}$ & $\begin{array}{l}18 e \\
18 f, h \\
18 d \\
18 h\end{array}$ \\
\hline $\begin{array}{l}17.6-18.0^{d} \\
15.5^{a}\end{array}$ & $\begin{array}{l}-(20.5-20.9)^{b} \\
-18.0^{a}\end{array}$ & $D_{\mathrm{e}}=22.2$ & & $\begin{array}{l}D_{\mathrm{e}}=14.6 \\
D_{\mathrm{e}}=14.6\end{array}$ & $\begin{array}{l}-8.8 \\
-10.9^{b}\end{array}$ & $\begin{array}{l}18 b \\
18 a \\
18 g \\
18 c\end{array}$ \\
\hline
\end{tabular}

${ }^{a}$ As calculated using the reported value for $D_{\mathrm{e}}$ and the reported vibrational frequencies. ${ }^{b}$ As calculated using the reported value of $\Delta_{\mathrm{r}} E_{298}^{0}$ $\left(\Delta_{\mathrm{r}} H_{298}^{0}=\Delta_{\mathrm{r}} E_{298}^{0}-R T\right.$ since one mole of gas is lost in the reaction). ${ }^{c}$ Based on the reported $D_{\mathrm{e}}$ and vibrational frequencies, the value of $\Delta_{\mathrm{r}} E_{298}^{0}$ these authors reported appears to be erroneous; the value of $\Delta_{\mathrm{r}} H_{298}^{0}$ listed here is based on their reported $\Delta_{\mathrm{r}} E_{298}^{0}$. ${ }^{d}$ As calculated using the reported values of $D_{\mathrm{e}}$ and by reproducing the reported electronic structure calculation to retrieve the predicted frequencies.

loss of the initial vibrational excitation. This mechanism is akin to that for collisionally stabilised association, with IVR taking the place of collisional stabilisation. In the limit where IVR is much slower than re-dissociation, one would expect a rather strong negative temperature-dependence of the relaxation rate constant, as for association reactions in the low pressure limit. ${ }^{7}$ Once again, comparisons of rate constants for hydrogenated and deuterated species, as well as measurements of the temperature-dependence of the relaxation rate, can provide useful information by altering the energy discrepancies for any $\mathrm{V}-\mathrm{V}$ relaxation channels.

Recently, we reported a rather extensive study of the relaxation of $\mathrm{OH}(v=1)$ and $\mathrm{OD}(v=1)$ by $\mathrm{HNO}_{3}$ and $\mathrm{DNO}_{3}{ }^{12}$ Rate coefficients for removal of the vibrationally excited radicals were measured for all four pairs of colliders in the temperature range from 253 to $383 \mathrm{~K}$. All four rate coefficients exhibit a fairly strong negative dependence on temperature. It was concluded that removal of the vibrationally excited $\mathrm{OH}$ (OD) radicals occurs via the formation of hydrogen-bonded cyclic complexes that had previously been invoked $^{13}$ to explain the unusual temperature- and pressuredependence of the rate constant for the chemical reaction of $\mathrm{OH}(v=0)$ with $\mathrm{HNO}_{3}$. However, in contrast to the systems where a strong chemical bond forms between the collision partners, in this case it was proposed that IVR and redissociation without loss of vibrational excitation in the $\mathrm{OH}$ (OD) radical occurred at comparable rates, so that the rate coefficients for relaxation were less than those for formation of the energised complex.

In the present paper, we report the results of a similar investigation to that on the $\mathrm{OH}(v=1), \operatorname{OD}(v=1)+$ $\mathrm{HNO}_{3}, \mathrm{DNO}_{3}$ system; this time on the relaxation of $\mathrm{OH}(v=1)$ and $\mathrm{OD}(v=1)$ by $\mathrm{H}_{2} \mathrm{O}$ and by $\mathrm{D}_{2} \mathrm{O}$. Recently, there have been two reports ${ }^{14,15}$ of the observation of the $\mathrm{H}_{2} \mathrm{O}-\mathrm{HO}$ hydrogen-bonded species by gas-phase rotational spectroscopy. In addition, there have been two reports ${ }^{16}$ of the infrared spectrum of $\mathrm{H}_{2} \mathrm{O}-\mathrm{HO}$ in solid argon matrices, as well as investigations ${ }^{17}$ of the potential energy surface for $\mathrm{H}_{2} \mathrm{O}-\mathrm{HO}$ using photoelectron spectroscopy. However, there has been no experimental determination of the dissociation energy of the hydrogen-bonded complex.

There have also been several theoretical studies ${ }^{18,19}$ of the $\mathrm{H}_{2} \mathrm{O}-\mathrm{HO}$ and $\mathrm{HOH}-\mathrm{OH}$ hydrogen-bonded complexes. The dissociation energies $\left(D_{0}\right)$ and bond enthalpies $\left(\Delta_{\mathrm{r}} H^{0}{ }_{298}\right)$ suggested by these studies are summarised in Table 1 . Several minima have been located on the potential energy surface. The consensus view (for example, ref. $18 g$ ) is that the lowest minimum is associated with a structure of ${ }^{2} A^{\prime}$ symmetry in which the $\mathrm{OH}$ radical acts as the proton donor and the water molecule the proton acceptor (which we shall refer to as $\mathrm{H}_{2} \mathrm{O}-\mathrm{HO}$ ), with a slightly weaker bond associated with the ${ }^{2} A$ " complex in which the roles are reversed; i.e., $\mathrm{H}_{2} \mathrm{O}$ is the proton donor and $\mathrm{OH}$ the proton acceptor (which we shall refer to as $\mathrm{HOH}-\mathrm{OH}$ ). In part, these theoretical studies focus on the path and energy barrier for the isotopic exchange reaction, $\mathrm{HO}+\mathrm{H}^{\prime} \mathrm{OH}^{\prime \prime} \rightarrow \mathrm{HOH}^{\prime}+\mathrm{OH}^{\prime \prime}$. Masgrau et al. ${ }^{18 d}$ concluded that this reaction proceeds via formation of the hydrogen-bonded $\mathrm{H}_{2} \mathrm{O}-\mathrm{HO}$ species followed by tunnelling through a substantial barrier to form the products. In addition, they estimated a rate constant for association to this complex of $3.7 \times 10^{-10} \mathrm{~cm}^{3}$ molecule $\mathrm{s}^{-1}$.

In the present work, rate coefficients for vibrational relaxation were measured using pulsed laser photolysis (PLP) to generate vibrationally excited $\mathrm{OH}(\mathrm{OD})$ and pulsed laserinduced fluorescence (PLIF) to detect the vibrationally excited radicals. This technique is quite similar to that which we employed to measure the rate coefficients for vibration relaxation of $\mathrm{OH}(v=1)$ and $\mathrm{OD}(v=1)$ by $\mathrm{HNO}_{3}$ and $\mathrm{DNO}_{3}{ }^{12}$ Using this method, we have measured rate coefficients, at temperatures between 251 and $390 \mathrm{~K}$, for the following processes:

$$
\begin{aligned}
& \mathrm{OH}(v=1)+\mathrm{H}_{2} \mathrm{O} \rightarrow \text { loss of } \mathrm{OH}(v=1) \\
& \mathrm{OH}(v=1)+\mathrm{D}_{2} \mathrm{O} \rightarrow \text { loss of } \mathrm{OH}(v=1) \\
& \mathrm{OD}(v=1)+\mathrm{H}_{2} \mathrm{O} \rightarrow \text { loss of } \mathrm{OD}(v=1) \\
& \mathrm{OD}(v=1)+\mathrm{D}_{2} \mathrm{O} \rightarrow \text { loss of } \mathrm{OD}(v=1)
\end{aligned}
$$

In general, the photochemistries that were used to produce $\mathrm{OH}(v=1)$ and $\mathrm{OD}(v=1)$ also produce significant amounts of the radicals in the $(v=2)$ vibrational state. We took advantage of this to measure the previously unreported rate coefficients at $c a .298 \mathrm{~K}$ for the following relaxation processes:

$$
\mathrm{OH}(v=2)+\mathrm{D}_{2} \mathrm{O} \rightarrow \text { loss of } \mathrm{OH}(v=2)
$$




$$
\begin{aligned}
& \mathrm{OD}(v=2)+\mathrm{H}_{2} \mathrm{O} \rightarrow \text { loss of } \mathrm{OD}(v=2) \\
& \mathrm{OD}(v=2)+\mathrm{D}_{2} \mathrm{O} \rightarrow \text { loss of } \mathrm{OD}(v=2)
\end{aligned}
$$

\section{Experimental details}

Rate coefficients for the processes represented by eqns (1) to (4) were measured using pulsed laser photolytic methods to produce $\mathrm{OH}(v>0)$ or $\mathrm{OD}(v>0)$ and pulsed LIF to detect $\mathrm{OH}$ or OD radicals in specific vibrational levels. Gas mixtures, containing the species required to create the vibrationally excited radicals and $\mathrm{H}_{2} \mathrm{O}$ or $\mathrm{D}_{2} \mathrm{O}$, were diluted to total pressures in the range 22 to 34 Torr with helium and flowed slowly through the reaction cell. The excess of $\mathrm{He}$ ensured complete translational and rotational equilibration of species, on a time scale much shorter than that associated with the kinetic observations that we report, but did not cause significant quenching of the LIF signals. The flow rate was fast enough to ensure that a fresh sample of gas mixture was exposed to successive shots from the photolysis laser. The apparatus which was employed in the present study has been used in numerous previous kinetic studies, including that in which rate coefficients were measured for the relaxation of $\mathrm{OH}(v=1)$ and $\mathrm{OD}(v=1)$ by $\mathrm{HNO}_{3}$ and $\mathrm{DNO}_{3},{ }^{12}$ and it is described in detail elsewhere. ${ }^{20}$ Here we focus on those aspects of our experimental procedure that were required for the present measurements.

Since it is not straightforward to generate vibrationally excited $\mathrm{OH}(\mathrm{OD})$ radicals by direct photolysis of $\mathrm{H}_{2} \mathrm{O}$ $\left(\mathrm{D}_{2} \mathrm{O}\right)$, it was necessary to include other photolytes in the gas mixtures; these are listed in Table 2. For measurements on process (1a), the relaxation of $\mathrm{OH}(v=1)$ by $\mathrm{H}_{2} \mathrm{O}$, three different schemes were used to generate $\mathrm{OH}(v=1)$ : (i) the direct photolysis of $\mathrm{HNO}_{3}$; (ii) the direct photolysis of $\mathrm{H}_{2} \mathrm{O}_{2}$; and (iii) the reaction between $\mathrm{O}\left({ }^{1} \mathrm{D}\right)$ atoms, produced from ozone photolysis, and $\mathrm{H}_{2} \mathrm{O}$. In all cases, photolysis was performed with the $248 \mathrm{~nm}$ output of an excimer laser operating on $\mathrm{KrF}$. The excimer laser beam $(c a .20-80 \mathrm{~mJ}$ per pulse and with a cross-sectional area of $\left.c a .1 .5 \mathrm{~cm}^{2}\right)$ was directed perpendicular to the gas flow. Photolysis of $\mathrm{HNO}_{3}$ at

Table 2 Source chemistry for production of vibrationally excited $\mathrm{OH} / \mathrm{OD}$

\begin{tabular}{llll}
\hline & & $\begin{array}{l}\text { Species } \\
\text { reacting } \\
\text { with } \mathrm{O}\left({ }^{1} \mathrm{D}\right)\end{array}$ & $\begin{array}{l}\text { Maximum } \\
v \text { level } \\
\text { accessible }\end{array}$ \\
\hline $\mathrm{OH}(v=1)+\mathrm{H}_{2} \mathrm{O}$ & $\mathrm{HNO}_{3}, \mathrm{H}_{2} \mathrm{O}_{2}$ & & $7,7^{b}$ \\
$\mathrm{OH}(v=1)+\mathrm{H}_{2} \mathrm{O}$ & $\mathrm{O}_{3}$ & $\mathrm{H}_{2} \mathrm{O}$ & 3 \\
$\mathrm{OH}(v=1,2)+\mathrm{D}_{2} \mathrm{O}$ & $\mathrm{O}_{3}$ & $\mathrm{CH}_{4}$ & 4 \\
$\mathrm{OD}(v=1,2)+\mathrm{H}_{2} \mathrm{O}$ & $\mathrm{O}_{3}$ & $\mathrm{CD}_{4}$ & 6 \\
$\mathrm{OD}(v=1,2)+\mathrm{D}_{2} \mathrm{O}$ & $\mathrm{O}_{3}$ & $\mathrm{D}_{2} \mathrm{O}$ & 4
\end{tabular}

${ }^{a}$ Species which reacts with $\mathrm{O}\left({ }^{1} \mathrm{D}\right)$ to produce vibrationally excited $\mathrm{OH}$ (OD). ${ }^{b}$ Although these are the highest levels accessible energetically from photodissociation at $248 \mathrm{~nm}$, the yield of $\mathrm{OH}(v>0)$ is small from both these photodissociations. The highest vibrational levels that have been observed to be populated are $v=2$ from $\mathrm{HNO}_{3}$ and $v=1$ from $\mathrm{H}_{2} \mathrm{O}_{2}$. There is further discussion in the text.
$248 \mathrm{~nm}$ is known to generate a small fraction $(c a .1 \%)$ of $\mathrm{OH}$ in $v=1$, roughly half that amount in $v=2$, and little or none in higher vibrational levels. ${ }^{12}$ The yield of $\mathrm{OH}(v=1)$ from photolysis of $\mathrm{H}_{2} \mathrm{O}_{2}$ at $248 \mathrm{~nm}$ is reported ${ }^{21}$ to be less than $1 \%$. Evidence from our own work indicates that the yield in higher vibrational levels is negligible. Moreover, using this source, the $\mathrm{OH}(v=1)$ LIF signal levels were quite low, indicating that the relative yield of $\mathrm{OH}(v=1)$ is significantly smaller from the photolysis of $\mathrm{H}_{2} \mathrm{O}_{2}$ than it is from $\mathrm{HNO}_{3}$.

In experiments on the relaxation of $\mathrm{OH}(v)$ by $\mathrm{D}_{2} \mathrm{O}$ and of $\mathrm{OD}(v)$ by $\mathrm{H}_{2} \mathrm{O}$ and $\mathrm{D}_{2} \mathrm{O}$, reactions of $\mathrm{O}\left({ }^{1} \mathrm{D}\right)$ were used to generate the vibrationally excited radicals, as indicated in Table 2. The reactions of $\mathrm{O}\left({ }^{1} \mathrm{D}\right)$ with $\mathrm{H}_{2} \mathrm{O}, \mathrm{D}_{2} \mathrm{O}, \mathrm{CH}_{4}$, and $\mathrm{CD}_{4}$ all produce vibrationally excited $\mathrm{OH}$ or $\mathrm{OD}$ in significant yields. Furthermore, the photolysis cross section of $\mathrm{O}_{3}$ and the quantum yield for production of $\mathrm{O}\left({ }^{1} \mathrm{D}\right)$ at $248 \mathrm{~nm}$ are both large. These factors combine to allow significant production of vibrationally excited $\mathrm{OH}$ or $\mathrm{OD}$ while using relatively small concentrations of photolytic precursors. This is important because species such as $\mathrm{H}_{2} \mathrm{O}, \mathrm{D}_{2} \mathrm{O}, \mathrm{HNO}_{3}, \mathrm{DNO}_{3}$, and, to a lesser extent, $\mathrm{CH}_{4}$ and $\mathrm{CD}_{4}$, efficiently quench the electronically excited $A^{2} \Sigma^{+}$state of $\mathrm{OH}(\mathrm{OD})$ which is excited during the LIF detection of vibrationally excited $\mathrm{OH}(\mathrm{OD})$ in our experiments. $\mathrm{CH}_{4}$ and $\mathrm{CD}_{4}$, instead of $\mathrm{H}_{2} \mathrm{O}$ and $\mathrm{D}_{2} \mathrm{O}$, were used as precursors of vibrationally excited $\mathrm{OH}$ and $\mathrm{OD}$ for measurements of processes (2) and (3) primarily because $\mathrm{CH}_{4}$ $\left(\mathrm{CD}_{4}\right)$ electronically quenches $A^{2} \Sigma^{+} \mathrm{OH}(\mathrm{OD})$ less efficiently than $\mathrm{H}_{2} \mathrm{O}\left(\mathrm{D}_{2} \mathrm{O}\right)$.

With the exception of $\mathrm{H}_{2} \mathrm{O}_{2}$ photolysis, all of the sources of $\mathrm{OH}(v=1)$ and $\mathrm{OD}(v=1)$ produce the radicals in vibrational states above $v=1$. Table 2 shows the highest thermodynamically accessible vibrational state for the $\mathrm{OH}(\mathrm{OD})$ product of the $\mathrm{O}\left({ }^{1} \mathrm{D}\right)$ reactions that we used. (For $\mathrm{O}\left({ }^{1} \mathrm{D}\right)+\mathrm{H}_{2} \mathrm{O}$, a small yield of $\mathrm{OH}(v=3)$ is observed, ${ }^{22}$ although this reaction is slightly endothermic.) Previous work has shown that the yield of $\mathrm{OH}(v \geq 2)$ is significant for $\mathrm{O}\left({ }^{1} \mathrm{D}\right)+\mathrm{H}_{2} \mathrm{O}^{23}$ and $\mathrm{O}\left({ }^{1} \mathrm{D}\right)+\mathrm{CH}_{4},{ }^{24}$ and that the yield of $\mathrm{OD}(v \geq 2)$ is significant from $\mathrm{O}\left({ }^{1} \mathrm{D}\right)+\mathrm{D}_{2} \mathrm{O} .{ }^{25}$ We are not aware of any reports of the yield of $\mathrm{OD}(v \geq 1)$ from $\mathrm{O}\left({ }^{1} \mathrm{D}\right)+\mathrm{CD}_{4}$, but we observed that significant $\mathrm{OD}$ is produced in at least $v=1,2,3$.

The presence of OH or OD in levels above $v=1$ presents a significant complication in our measurements of rate coefficients for the relaxation of $\mathrm{OH}(v=1)$ and $\mathrm{OD}(v=1)$, because radicals in these higher vibrational states are relaxed into $(v=1)$ as the population in that level is being simultaneously removed. Thus, the temporal profiles for the vibrationally excited radicals are not single-exponential decays. The analysis of these temporal profiles is discussed in the next section.

Vibrationally excited OH (OD) radicals were observed using LIF. The second harmonic of a tuneable dye laser pumped by the second harmonic of a pulsed Nd:YAG laser $(\lambda=532 \mathrm{~nm})$ was passed through the reaction cell, perpendicular to both the gas flow and the photolysis laser. This probe laser excited a specific rotational line in the $A^{2} \Sigma^{+}(v=0) \leftarrow X^{2} \Pi(v=1)$ band of $\mathrm{OH}$ or $\mathrm{OD}$, in order to detect $\mathrm{OH}(v=1)$ or $\mathrm{OD}(v=1)$, or in the $A^{2} \Sigma^{+}(v=1) \leftarrow X^{2} \Pi(v=2)$ band, to detect $\mathrm{OH}(v=2)$ or $\mathrm{OD}(v=2)$. The $\mathrm{Q}_{1}(1)$ lines in these bands were used, except for measurements on $\operatorname{OD}(v=2)$. In this case the $\mathrm{Q}_{1}(1)$ line could not be used because it is too close in 
wavelength to several OD $A^{2} \Sigma^{+}(v=0) \leftarrow X^{2} \Pi(v=1)$ transitions. The wavelength used for $\operatorname{OD}(v=2)$ excited both the $\mathrm{R}_{2}(1)$ and $\mathrm{P}_{1}(4)$ lines.

$\mathrm{OH}(\mathrm{OD}) A^{2} \Sigma^{+} \rightarrow X^{2} \Pi$ fluorescence passed through a band-pass filter (peak transmission at $307.5 \mathrm{~nm}$, FWHM 10 $\mathrm{nm}$ ) and was detected with a photomultiplier tube (PMT) positioned orthogonally to the laser beams. When OH (OD) $X$ ${ }^{2} \Pi(v=1)$ was excited to $A^{2} \Sigma^{+}(v=0)$, emission in the $A^{2} \Sigma^{+}$ $(v=0) \rightarrow X^{2} \Pi(v=0)$ band $(\lambda \approx 308 \mathrm{~nm}$ for both $\mathrm{OH}$ and OD) was transmitted by the band-pass filter and detected. When $\mathrm{OH}(\mathrm{OD}) X^{2} \Pi(v=2)$ was excited to $A^{2} \Sigma^{+}(v=1)$, emission from two bands was detected: directly excited emission in the $(1,1)$ band ( $\lambda \approx 313 \mathrm{~nm}$ for $\mathrm{OH}, 311 \mathrm{~nm}$ for $\mathrm{OD})$, and, after vibrational relaxation of $\mathrm{OH}(\mathrm{OD}) A^{2} \Sigma^{+}(v=1)$, emissions in the $(0,0)$ band. Temporal profiles of the LIF signals were generated by varying the time delay between the pulses from the photolysis and probe lasers.

The LIF detection scheme that was adopted had several advantages. Because the excitation wavelengths (in the range 334-351 nm) were longer than those of the LIF signals (at ca. $308 \mathrm{~nm}$ ) any scattered light would have to have been blue shifted to be detected. Furthermore, species such as $\mathrm{HNO}_{3}$ and $\mathrm{O}_{3}$ have negligible photolysis cross sections at the excitation wavelengths, so the probe laser did not produce significant amounts of $\mathrm{OH}(v=1)$ or $\mathrm{OD}(v=1)$.

$\mathrm{H}_{2} \mathrm{O}$ or $\mathrm{D}_{2} \mathrm{O}$ was introduced into the reaction cell by bubbling a small flow of $\mathrm{He}$ through either distilled $\mathrm{H}_{2} \mathrm{O}$ or $\mathrm{D}_{2} \mathrm{O}$ (Aldrich, 99.9\% atom $\mathrm{D}$ ). The flow from this bubbler, which was at room temperature, was then passed through a second bubbler, which was kept below room temperature (typically $0{ }^{\circ} \mathrm{C}$ for $\mathrm{H}_{2} \mathrm{O}$ and 5 or $10{ }^{\circ} \mathrm{C}$ for $\mathrm{D}_{2} \mathrm{O}$ ). We assumed that the flow left the second bubbler saturated with $\mathrm{H}_{2} \mathrm{O}\left(\mathrm{D}_{2} \mathrm{O}\right)$ at the temperature of that bubbler. The concentration of $\mathrm{H}_{2} \mathrm{O}$ $\left(\mathrm{D}_{2} \mathrm{O}\right)$ in the reaction cell was calculated using the saturation vapour pressure of $\mathrm{H}_{2} \mathrm{O}^{26}$ or $\mathrm{D}_{2} \mathrm{O}^{27}$ at the temperature of the second bubbler and dilution factors based on the various flows, the temperature of the reaction cell, and the pressures of the second bubbler and the reaction cell. We estimate that the concentration of $\mathrm{H}_{2} \mathrm{O}\left(\mathrm{D}_{2} \mathrm{O}\right)$ in the reaction cell had an uncertainty of $c a .9 \%$ associated with an estimated uncertainty of $\pm 0.5 \mathrm{~K}(2 \sigma)$ in the temperature of the second bubbler and the uncertainty in the dilution factors. Rate coefficients below room temperature were measured with partial pressures of $\mathrm{H}_{2} \mathrm{O}\left(\mathrm{D}_{2} \mathrm{O}\right)$ at least three times lower than the saturation vapour pressures of these compounds over solid $\mathrm{H}_{2} \mathrm{O}^{28}$ or $\mathrm{D}_{2} \mathrm{O}^{29}$ at the temperature of the reaction cell.

Anhydrous $\mathrm{HNO}_{3}$ and $\mathrm{DNO}_{3}$ were prepared by vacuum distillation of the nitric acid formed by the addition of $\mathrm{H}_{2} \mathrm{SO}_{4}$ or $\mathrm{D}_{2} \mathrm{SO}_{4}$ to $\mathrm{NaNO}_{3}$ and stored at reduced temperature in glass bubblers. Gas-phase $\mathrm{HNO}_{3}$ and/or $\mathrm{DNO}_{3}$ was introduced into the gas flow by bubbling a small flow of $\mathrm{He}$ through the liquid acid in the bubbler. Gas phase $\mathrm{H}_{2} \mathrm{O}_{2}$ was introduced into the system by flowing a small amount of He through a concentrated aqueous solution of hydrogen peroxide (estimated to be $>95 \%$ by titration with potassium permanganate).

Ozone was prepared by passing ultra-high purity (UHP) $\mathrm{O}_{2}$ through an electrical discharge and then trapping the $\mathrm{O}_{3}$ that was formed on silica gel at $c a .197 \mathrm{~K}$. Dilute ( $c a .200 \mathrm{ppmv}$ ) mixtures of $\mathrm{O}_{3}$ in $\mathrm{He}$ were then prepared manometrically and stored in darkened 121 glass bulbs. Methane and per-deuteromethane (UHP grade) were used as supplied. Helium (UHP grade) was also used directly out of its cylinder.

\section{Data analysis and estimates of errors}

For each of the rate coefficients presented here, with the exception of the measurement of $\mathrm{OH}(v=1)$ relaxation by $\mathrm{H}_{2} \mathrm{O}$ when $\mathrm{H}_{2} \mathrm{O}_{2}$ was used as the photolyte, temporal profiles of the concentrations of vibrationally excited radicals observed by PLIF were not single-exponential. This was due to the presence of higher vibrational states of the $\mathrm{OH}$ or $\mathrm{OD}$ radical being relaxed into the vibrational state being monitored. The temporal profiles were fit to an expression of the form, here given for the relaxation of $\mathrm{OH}(v=1)$

$$
\begin{aligned}
& {[\mathrm{OH}(v=1)]_{t}=[\mathrm{OH}(v=1)]_{0} \exp \left(-k_{v 1} t\right)} \\
& +\frac{k_{v 2 a}[\mathrm{OH}(v=2)]_{0}}{k_{v 1}-k_{v 2}}\left[\exp \left(-k_{v 2} t\right)-\exp \left(-k_{v 1} t\right)\right]
\end{aligned}
$$

In this expression, $[\mathrm{OH}(v=1)]_{t}$ is the concentration of $\mathrm{OH}(v=1)$ at time $t$, while $[\mathrm{OH}(v)]_{0}$ are initial concentrations in the specified vibrational states immediately after $\mathrm{OH}$ is formed by photolysis or by the reactions of $\mathrm{O}\left({ }^{1} \mathrm{D}\right) . k_{v 1}{ }^{\prime}$ and $k_{v 2}{ }^{\prime}$ are the pseudo-first order rate coefficients (i.e., the products of the bimolecular rate coefficients and the relaxer concentrations) for the relaxation of $\mathrm{OH}(v=1)$ and $\mathrm{OH}$ $(v=2)$, respectively; while $k_{v 2 \mathrm{a}}{ }^{\prime}$ is the rate coefficient for the specific relaxation of $\mathrm{OH}(v=2)$ into $\mathrm{OH}(v=1)$. The measured temporal profiles were fit to this form, with the assumption that $k_{v 2 \mathrm{a}}{ }^{\prime}=k_{v 2}{ }^{\prime}$. We made this assumption because $k_{v 2 \mathrm{a}^{\prime}}$ and [OH $\left.(v=2)\right]_{0}$ are not independent variables in the temporal expression; this assumption does not affect the measured values of the relaxation rate coefficients. The temporal profiles were fitted well by this expression. Analogous expressions are used when measuring the relaxation of $\mathrm{OH}$ $(v=2)$, with $\mathrm{OH}(v=2)$ and $\mathrm{OH}(v=3)$ replacing $\mathrm{OH}(v=1)$ and $\mathrm{OH}(v=2)$, respectively, and for the relaxation of OD $(v=1)$ and $\operatorname{OD}(v=2)$. Fig. 1 shows three examples of fitted temporal profiles for $\mathrm{OH}(v=1)$ being relaxed by approximately the same concentration of $\mathrm{H}_{2} \mathrm{O}$ but with different photolytic sources of vibrationally excited $\mathrm{OH}$.

$\mathrm{HNO}_{3}$ photolysis at $248 \mathrm{~nm}$ produces little or no $\mathrm{OH}$ $(v>2)$. Thus, the above temporal expression is a correct representation of the kinetics of $\mathrm{OH}(v=1)$ relaxation when this source of $\mathrm{OH}(v=1)$ was used. However, the $\mathrm{O}\left({ }^{1} \mathrm{D}\right)$ reactions we used generally produce significant amounts of $\mathrm{OH}(v>2)$ or $\mathrm{OD}(v>2))$. Nevertheless, we found that this simplified two-state treatment of the temporal profiles led to rate coefficients for removal of $\mathrm{OH}(v=1)$ and $\mathrm{OD}(v=1)$ that were independent of the source of the vibrationally excited radicals. Generally, removal of vibrationally excited $\mathrm{OH}$ or OD becomes faster for higher vibrational states. Thus, the time scale for loss of $\mathrm{OH}(v>2)$ is shorter than that for the decay of $\mathrm{OH}(v=1)$, so that relaxation of $\mathrm{OH}(v>2)$ has little impact on the measured rate coefficient for removal of $\mathrm{OH}(v=1)$.

To estimate the magnitude of the error which results from using this two-state approximation, we numerically modelled 


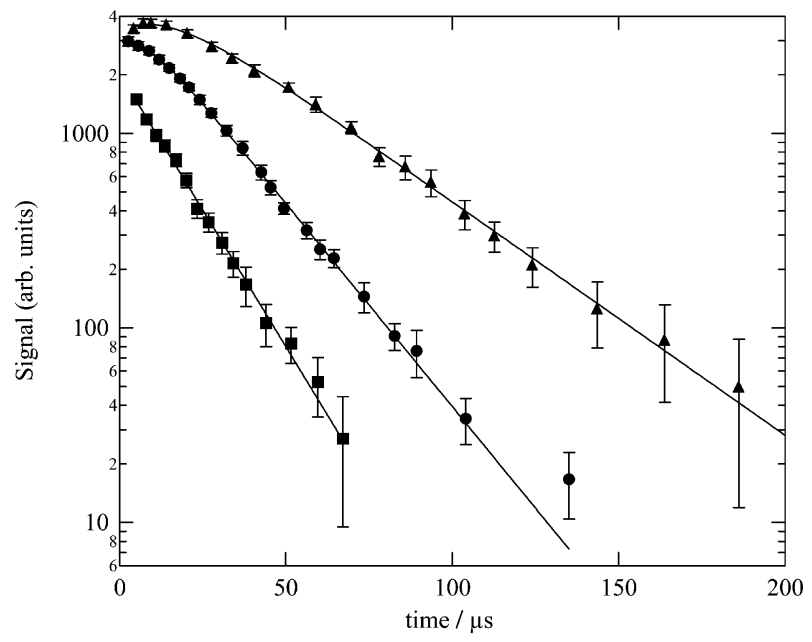

Fig. 1 Temporal profiles of PLIF signals from $\mathrm{OH}(v=1)$, produced using different photochemistries, during relaxation by $c a .2 .5 \times 10^{15}$ molecule $\mathrm{cm}^{-3}$ of $\mathrm{H}_{2} \mathrm{O}$ at $296 \mathrm{~K}$. Photolytic sources: triangles $(\boldsymbol{\Delta})$, $\mathrm{O}\left({ }^{1} \mathrm{D}\right)+\mathrm{H}_{2} \mathrm{O}\left(\left[\mathrm{O}\left({ }^{1} \mathrm{D}\right)\right]_{0}=6.7 \times 10^{11}\right.$ molecule $\left.\mathrm{cm}^{-3}\right)$; circles $(\mathbf{O})$, $\mathrm{HNO}_{3}$ photolysis $\left(\left[\mathrm{HNO}_{3}\right]=6.0 \times 10^{14}\right.$ molecule $\left.\mathrm{cm}^{-3}\right)$; squares $(\boldsymbol{\square})$, $\mathrm{H}_{2} \mathrm{O}_{2}$ photolysis $\left(\left[\mathrm{H}_{2} \mathrm{O}_{2}\right]=6.5 \times 10^{14}\right.$ molecule $\left.\mathrm{cm}^{-3}\right)$. The curvature at short times, due to relaxation from higher vibrational states of $\mathrm{OH}$ into $(v=1)$, is clear in the temporal profiles when $\mathrm{O}\left({ }^{1} \mathrm{D}\right)+\mathrm{H}_{2} \mathrm{O}$ and $\mathrm{HNO}_{3}$ photolysis are used as sources of $\mathrm{OH}(v=1)$. The lines are fits of the data to the expression on the right-hand side of (eqn (1)), except for the signals from $\mathrm{OH}(v=1)$, produced by $\mathrm{H}_{2} \mathrm{O}_{2}$ photolysis, which were fit to a single exponential function. The large differences in the pseudo-first order rate coefficients measured here are due to the relaxation of $\mathrm{OH}(v=1)$ by the photolytes.

several systems using a stepwise relaxation mechanism, where only one quantum of vibrational energy is lost per 'reaction'; that is,

$$
\mathrm{OH}(v=n)+\mathrm{Q} \rightarrow \mathrm{OH}(v=n-1)+\mathrm{Q}
$$

As inputs for the model, we used yields for the vibrational states of $\mathrm{OH}(\mathrm{OD})$ from the $\mathrm{O}\left({ }^{1} \mathrm{D}\right)$ reactions and rate coefficients for relaxation of $\mathrm{OH}(\mathrm{OD})$ from levels $v=1-4$ at $298 \mathrm{~K}$ from the literature or estimated from our data. The literature sources, and details of the models and results, are given elsewhere. ${ }^{30}$ The model results indicate that using the twostate approximation potentially results in errors of $10 \%$ or less for the rate coefficients for relaxation of $\mathrm{OH}(v=1)$, but the errors could be as high as 20 and $30 \%$ for the relaxation of $\mathrm{OD}(v=1)$ by $\mathrm{H}_{2} \mathrm{O}$ and $\mathrm{D}_{2} \mathrm{O}$, respectively. It is possible that vibrationally excited $\mathrm{OH}(\mathrm{OD})$ is removed by multi-quantum relaxation and, in the cases involving unlike isotopes, isotopeexchange reactions. If either process occurs, it will reduce the error due to the two-state approximation, because these processes would either decrease the amount of $\mathrm{OH}$ (OD) being relaxed into the state being monitored or would speed up the process of relaxing the higher states into the state being monitored.

At a given temperature, temporal profiles of the vibrationally excited radicals were recorded at a number of concentrations of the relaxing species $\left(\mathrm{H}_{2} \mathrm{O}\right.$ or $\left.\mathrm{D}_{2} \mathrm{O}\right)$. The fitted values of $k_{\mathrm{v} 1}{ }^{\prime}$ from the above expression were then plotted against

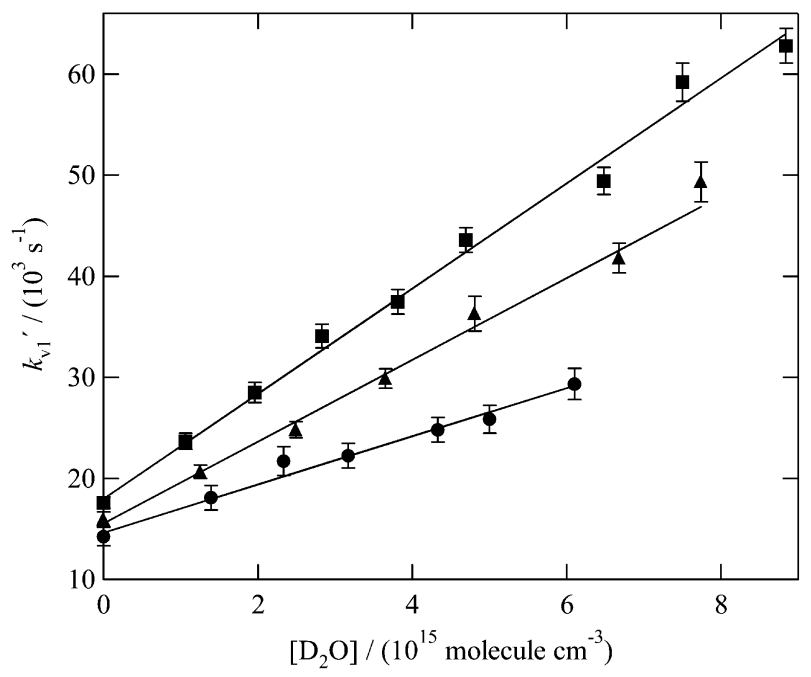

Fig. 2 Plots of $k_{\mathrm{v} 1}{ }^{\prime}$ for $\mathrm{OH}(v=1)$ relaxation by $\mathrm{D}_{2} \mathrm{O}$ versus the concentration of $\mathrm{D}_{2} \mathrm{O}$ at three temperatures: squares $(\mathbf{\square}), 256 \mathrm{~K}$; triangles $(\mathbf{\Delta}), 296 \mathrm{~K}$; circles $(\mathbf{O}), 371 \mathrm{~K}$. Error bars are the statistical uncertainty $(2 \sigma)$ from the fits of the temporal profiles. Lines are linear least-squares fits of these data and their slopes are the bimolecular rate coefficients $k_{2 \mathrm{a}}$. The large $y$-intercept is due to quenching of $\mathrm{OH}(v=1)$ by the photochemical precursors of $\mathrm{OH}(v=1)$.

the concentration of the relaxing species; the weighted linear least-squares fits for the slope of these plots are the bimolecular rate coefficients for the relaxation of $\mathrm{OH}(v=1)$ or $\mathrm{OD}(v=1)$. Fig. 2 shows examples of $k_{\mathrm{v} 1}{ }^{\prime}$ for $\mathrm{OH}(v=1)$ plotted versus $\left[\mathrm{D}_{2} \mathrm{O}\right]$ yielding values of $k_{2 \mathrm{a}}$ at three different temperatures.

\section{Experimental results}

The rate coefficients for processes (1a) to (4b) at different temperatures are listed in Table 3, together with the photolytic sources of vibrationally excited $\mathrm{OH}$ (OD) and the concentrations of photolytes and relaxing species. We draw attention to the similarity of the values obtained for the relaxation of $\mathrm{OH}(v=1)$ by $\mathrm{H}_{2} \mathrm{O}$ at $297 \mathrm{~K}$ using three different sources of the vibrationally excited radical. It is especially reassuring to note that the rate coefficient obtained using the reaction between $\mathrm{O}\left({ }^{1} \mathrm{D}\right)$ atoms and $\mathrm{H}_{2} \mathrm{O}$ agrees with those using photolysis of $\mathrm{HNO}_{3}$ and $\mathrm{H}_{2} \mathrm{O}_{2}$, since cascading effects are likely to be most significant in the first case, and because reactions of $\mathrm{O}\left({ }^{1} \mathrm{D}\right)$ are used to generate vibrationally excited $\mathrm{OH}(\mathrm{OD})$ in order to determine rate coefficients for the other isotopically related process $(2 \mathrm{a})$ to $(4 \mathrm{a})$.

The second-order rate coefficients reported in Table 3 are derived from plots of the first-order rate constants $\left(k_{v 1}{ }^{\prime}\right)$, derived from the analysis of the variation of LIF signals versus delay times, versus the concentrations of $\mathrm{H}_{2} \mathrm{O}$ or $\mathrm{D}_{2} \mathrm{O}$ included in the gas mixtures. The uncertainty of the weighted fits of $k_{v 1}{ }^{\prime}$ versus $\left[\mathrm{H}_{2} \mathrm{O}\right]$ or $\left[\mathrm{D}_{2} \mathrm{O}\right]$ was typically $2-10 \%(2 \sigma)$. We estimate that uncertainties in the temperature of the bubbler used to control the concentration of $\mathrm{H}_{2} \mathrm{O}\left(\mathrm{D}_{2} \mathrm{O}\right)$ and in measurement of the flows lead to an uncertainty of $\pm 9 \%$ $(2 \sigma)$ for the concentration of $\mathrm{H}_{2} \mathrm{O}\left(\mathrm{D}_{2} \mathrm{O}\right)$ in the LIF cell. 
Table 3 Experimental conditions and measured rate coefficients $\left(k / 10^{-12} \mathrm{~cm}^{3}\right.$ molecule $\left.{ }^{-1} \mathrm{~s}^{-1}\right)$

\begin{tabular}{|c|c|c|c|c|c|c|c|c|c|}
\hline Process & $T / \mathrm{K}$ & $\mathrm{OH}$ source & $\begin{array}{l}{\left[\mathrm{HNO}_{3}\right] \text { or }} \\
{\left[\mathrm{H}_{2} \mathrm{O}_{2}\right] /} \\
10^{14} \mathrm{~cm}^{-3}\end{array}$ & $\begin{array}{l}{\left[\mathrm{H}_{2} \mathrm{O}\right] / 10^{15}} \\
\mathrm{~cm}^{-3}\end{array}$ & $\begin{array}{l}{\left[\mathrm{D}_{2} \mathrm{O}\right] / 10^{15}} \\
\mathrm{~cm}^{-3}\end{array}$ & $\begin{array}{l}{\left[\mathrm{O}_{3}\right] / 10^{11}} \\
\mathrm{~cm}^{-3}\end{array}$ & $\begin{array}{l}{\left[\mathrm{CH}_{4}\right] / 10^{16}} \\
\mathrm{~cm}^{-3}\end{array}$ & $\begin{array}{l}{\left[\mathrm{CD}_{4}\right] / 10^{15}} \\
\mathrm{~cm}^{-3}\end{array}$ & $k \pm 2 \sigma$ \\
\hline $\mathrm{OH}(v=1)+\mathrm{H}_{2} \mathrm{O}$ & $\begin{array}{l}263 \\
296 \\
297 \\
297 \\
321 \\
348 \\
390\end{array}$ & $\begin{array}{l}\mathrm{HNO}_{3}+h v \\
\mathrm{O}\left({ }^{1} \mathrm{D}\right)+\mathrm{H}_{2} \mathrm{O} \\
\mathrm{HNO}_{3}+h v \\
\mathrm{H}_{2} \mathrm{O}_{2}+h v \\
\mathrm{O}\left({ }^{1} \mathrm{D}\right)+\mathrm{H}_{2} \mathrm{O} \\
\mathrm{HNO}_{3}+h v \\
\mathrm{HNO}_{3}+h v\end{array}$ & $\begin{array}{r}8.8-17.9 \\
\\
5.2-7.9 \\
6.1-7.8 \\
7.1-14.7 \\
10.9-17.0\end{array}$ & $\begin{array}{r}0-6.43 \\
2.27-16.8 \\
0-9.54 \\
0-8.99 \\
0.99-7.73 \\
0-4.28 \\
0-3.34\end{array}$ & & $\begin{array}{l}24.3 \\
11.0\end{array}$ & & & $\begin{aligned} 13.9 & \pm 2.0 \\
12.3 & \pm 1.7 \\
11.7 & \pm 1.7 \\
10.6 & \pm 1.6 \\
9.7 & \pm 1.4 \\
9.1 & \pm 1.7 \\
8.1 & \pm 1.4\end{aligned}$ \\
\hline $\mathrm{OH}(v=1)+\mathrm{D}_{2} \mathrm{O}$ & $\begin{array}{l}256 \\
274 \\
296 \\
332 \\
371\end{array}$ & $\begin{array}{l}\mathrm{O}\left({ }^{1} \mathrm{D}\right)+\mathrm{CH}_{4} \\
\mathrm{O}\left({ }^{1} \mathrm{D}\right)+\mathrm{CH}_{4} \\
\mathrm{O}\left({ }^{1} \mathrm{D}\right)+\mathrm{CH}_{4} \\
\mathrm{O}\left({ }^{1} \mathrm{D}\right)+\mathrm{CH}_{4} \\
\mathrm{O}\left({ }^{1} \mathrm{D}\right)+\mathrm{CH}_{4}\end{array}$ & & & $\begin{array}{l}0-8.84 \\
0-7.11 \\
0-7.67 \\
0-6.75 \\
0-6.10\end{array}$ & $\begin{array}{l}3.5 \\
4.4 \\
2.9 \\
2.7 \\
6.3\end{array}$ & $\begin{array}{l}2.8 \\
2.6 \\
2.4 \\
2.2 \\
2.2\end{array}$ & & $\begin{array}{l}5.2 \pm 0.7 \\
4.5 \pm 0.8 \\
4.0 \pm 0.7 \\
3.1 \pm 0.5 \\
2.4 \pm 0.4\end{array}$ \\
\hline $\mathrm{OD}(v=1)+\mathrm{H}_{2} \mathrm{O}$ & $\begin{array}{l}251 \\
272 \\
298 \\
334 \\
371\end{array}$ & $\begin{array}{l}\mathrm{O}\left({ }^{1} \mathrm{D}\right)+\mathrm{CD}_{4} \\
\mathrm{O}\left({ }^{1} \mathrm{D}\right)+\mathrm{CD}_{4} \\
\mathrm{O}\left({ }^{1} \mathrm{D}\right)+\mathrm{CD}_{4} \\
\mathrm{O}\left({ }^{1} \mathrm{D}\right)+\mathrm{CD}_{4} \\
\mathrm{O}\left({ }^{1} \mathrm{D}\right)+\mathrm{CD}_{4}\end{array}$ & & $\begin{array}{l}0-5.38 \\
0-5.23 \\
0-5.68 \\
0-4.74 \\
0-4.39\end{array}$ & & $\begin{array}{l}5.3 \\
4.8 \\
4.8 \\
4.1 \\
3.9\end{array}$ & & $\begin{array}{l}7.3 \\
6.9 \\
6.1 \\
5.5 \\
5.0\end{array}$ & $\begin{array}{l}6.3 \pm 0.8 \\
5.7 \pm 0.6 \\
4.7 \pm 0.5 \\
3.9 \pm 0.4 \\
3.4 \pm 0.4\end{array}$ \\
\hline $\mathrm{OD}(v=1)+\mathrm{D}_{2} \mathrm{O}$ & $\begin{array}{l}253 \\
298 \\
366\end{array}$ & $\begin{array}{l}\mathrm{O}\left({ }^{1} \mathrm{D}\right)+\mathrm{D}_{2} \mathrm{O} \\
\mathrm{O}\left({ }^{1} \mathrm{D}\right)+\mathrm{D}_{2} \mathrm{O} \\
\mathrm{O}\left({ }^{1} \mathrm{D}\right)+\mathrm{D}_{2} \mathrm{O}\end{array}$ & & & $\begin{array}{l}1.15-4.57 \\
0.91-5.43 \\
1.03-4.29\end{array}$ & $\begin{array}{l}4.3 \\
4.4 \\
3.7\end{array}$ & & & $\begin{array}{l}9.9 \pm 1.6 \\
8.1 \pm 1.0 \\
6.5 \pm 0.8\end{array}$ \\
\hline $\mathrm{OH}(v=2)+\mathrm{D}_{2} \mathrm{O}$ & 296 & $\mathrm{O}\left({ }^{1} \mathrm{D}\right)+\mathrm{CH}_{4}$ & & & $0-5.46$ & 7.0 & 2.6 & & $15.5 \pm 3.3$ \\
\hline $\mathrm{OD}(v=2)+\mathrm{H}_{2} \mathrm{O}$ & 297 & $\mathrm{O}\left({ }^{1} \mathrm{D}\right)+\mathrm{CD}_{4}$ & & $0-7.42$ & & 8.1 & & 5.3 & $14.3 \pm 1.7$ \\
\hline $\mathrm{OD}(v=2)+\mathrm{D}_{2} \mathrm{O}$ & 298 & $\mathrm{O}\left({ }^{1} \mathrm{D}\right)+\mathrm{D}_{2} \mathrm{O}$ & & & $1.30-5.93$ & 3.8 & & & $12.9 \pm 1.6$ \\
\hline
\end{tabular}

The uncertainties listed for the rate coefficients in Table 3 are the sum (not in quadrature) of this uncertainty and the statistical error.

In Table 4, we compare the weighted average of the three values of $k_{1 \mathrm{a}}$ that we have determined at $c a$. $298 \mathrm{~K}$ with rate coefficients for this process reported in the literature. ${ }^{3,22,31}$ The agreement is very satisfactory, especially when account is taken of the fact that the values of $k_{1 \mathrm{a}}$ and $k_{1 \mathrm{~b}}$ reported by Bradshaw et al. ${ }^{31 a}$ were derived from single kinetic traces. The small differences between the results from different studies are probably due to the difficulty of quantifying the concentrations of water vapour in our experiments and those of others.
The values of the rate coefficients listed in Table 4 for relaxation of $\mathrm{OH}(v=1)$ and $\mathrm{OD}(v=1)$ by $\mathrm{H}_{2} \mathrm{O}$ and $\mathrm{D}_{2} \mathrm{O}$ exhibit a clear, and moderately strong, negative dependence on temperature; that is, the rate coefficients increase as the temperature is lowered. We have matched the rate coefficients to two analytical expressions: (i) the Arrhenius equation $k(T)=A \exp \left(-E_{\text {act }} / \mathrm{R} T\right)$, yielding a negative activation energy, and (ii) the form $k(T)=k(298)(T / 298)^{-n}$. The fitting parameters are given in Table 5. Fig. 3, in which logarithmic values of the rate coefficients are plotted against the reciprocal of temperature, displays the quality of the fit to the Arrhenius expression. An equally good fit is obtained when

Table 4 Measured values of the rate coefficient for vibrational relaxation of $\mathrm{OH}(v=1), k_{1 \mathrm{a}}$, and $\mathrm{OH}(v=2), k_{1 \mathrm{~b}}$, by $\mathrm{H}_{2} \mathrm{O}$ at $c a$. $298 \mathrm{~K}$

\begin{tabular}{|c|c|c|c|c|}
\hline$k_{1 \mathrm{~b}} / \mathrm{cm}^{3}$ molecule ${ }^{-1} \mathrm{~s}^{-1}$ & $k_{1 \mathrm{a}} / \mathrm{cm}^{3}$ molecule ${ }^{-1} \mathrm{~s}^{-1}$ & Method & {$\left[\mathrm{H}_{2} \mathrm{O}\right]$ measurement } & Ref. \\
\hline $3.66 \times 10^{-11}$ & $2.09 \times 10^{-11}$ & $\mathrm{O}_{3}$ photolysis; $\mathrm{O}\left({ }^{1} \mathrm{D}\right)+\mathrm{H}_{2} \mathrm{O} ;$ LIF detection & $\begin{array}{l}185 \mathrm{~nm} \text { absorption } \\
\left(\sigma=7.2 \times 10^{-20} \mathrm{~cm}^{2}\right)\end{array}$ & $22^{a}$ \\
\hline \multirow[t]{2}{*}{$2.58 \times 10^{-11}$} & $1.33 \times 10^{-11}$ & $\begin{array}{l}\text { Continuous } \mathrm{OH} \text { from } \mathrm{H}+\mathrm{NO}_{2} ; \mathrm{OH}(v=0) \\
\text { excited to }(v=2) \text { by IR radiation from } \\
\text { Raman-shifted dve laser. LIF detection. }\end{array}$ & Capacitance hygrometer & $31 c$ \\
\hline & $1.36 \times 10^{-11}$ & $\begin{array}{l}\mathrm{OH}(v=1) \text { from flashlamp photolysis of } \\
\mathrm{HNO}_{3}, \text { LIF detection. }\end{array}$ & $\begin{array}{l}\text { Manometric preparation } \\
\text { of } \mathrm{H}_{2} \mathrm{O} / \mathrm{Ar} \text { mixtures }\end{array}$ & 3 \\
\hline \multirow[t]{4}{*}{$7 \times 10^{-11}$} & $3 \times 10^{-11}$ & $\begin{array}{l}\mathrm{O}\left({ }^{1} \mathrm{D}\right)+\mathrm{H}_{2} \mathrm{O} \text { production of } \mathrm{OH}, \mathrm{LIF} \\
\text { (Rate constant from one temporal profile). }\end{array}$ & Not reported & \\
\hline & $1.4 \times 10^{-11}$ & $\begin{array}{l}\text { Flow tube kinetics; } \mathrm{OH}(v=1) \text { directly from } \\
\mathrm{H}+\mathrm{NO}_{2} ; \text { EPR detection of } \mathrm{OH} \text {. }\end{array}$ & Not reported & $31 a$ \\
\hline & $1.35 \times 10^{-11}$ & $\begin{array}{l}\text { Flow tube kinetics; } \mathrm{OH}(v=1) \text { directly from } \\
\mathrm{O}+\mathrm{HBr} \text {; EPR detection of } \mathrm{OH}\end{array}$ & Not reported & $31 d$ \\
\hline & $1.15 \times 10^{-11}$ & See text & See text & This work \\
\hline
\end{tabular}


Table 5 Parameters describing temperature-dependence of rate coefficients

\begin{tabular}{|c|c|c|c|c|}
\hline \multirow[b]{2}{*}{ Process } & \multicolumn{2}{|c|}{$k(T)=A e^{-E_{a} / R T}$} & \multicolumn{2}{|c|}{$k(T)=k(298)(T / 298)^{-n}$} \\
\hline & $A^{b}$ & $E_{a} / R / \mathrm{K}$ & $k(298)^{c}$ & $n$ \\
\hline $\mathrm{OH}(v=1)+\mathrm{H}_{2} \mathrm{O}$ & $24 \pm 9$ & $-460 \pm 115$ & $11.5 \pm 0.5$ & $1.47 \pm 0.40$ \\
\hline $\mathrm{OH}(v=1)+\mathrm{D}_{2} \mathrm{O}$ & $4.9 \pm 1.6$ & $-610 \pm 90$ & $3.85 \pm 0.09$ & $2.04 \pm 0.19$ \\
\hline $\mathrm{OD}(v=1)+\mathrm{H}_{2} \mathrm{O}$ & $9.2 \pm 1.6$ & $-485 \pm 48$ & $4.77 \pm 0.08$ & $1.63 \pm 0.13$ \\
\hline $\mathrm{OD}(v=1)+\mathrm{D}_{2} \mathrm{O}$ & $25.7 \pm 0.9$ & $-342 \pm 10$ & $8.18 \pm 0.11$ & $1.14 \pm 0.09$ \\
\hline
\end{tabular}

the experimental data are fitted to the second, power law, expression. The error bars shown on the points in Fig. 3 represent only the statistical uncertainties.

\section{Theoretical calculations}

In order to examine further whether the relaxation of $\mathrm{OH}(v=$ 1) and $\mathrm{OD}(v=1)$ by $\mathrm{H}_{2} \mathrm{O}$ and $\mathrm{D}_{2} \mathrm{O}$ might proceed via the formation of hydrogen-bonded complexes, we have adapted a method of Troe ${ }^{32}$ that was originally designed to treat association reactions (e.g., of $\mathrm{A}$ with $\mathrm{B}$ ) in the limit of low pressure. The mechanism considered by Troe can be written:

$$
\mathrm{A}+\mathrm{B} \underset{k_{\text {diss }}}{\stackrel{k_{\text {ass }}}{\rightleftarrows}}(\mathrm{AB})^{*} \stackrel{k_{\mathrm{M}}[\mathrm{M}]}{\longrightarrow}(\mathrm{AB})
$$

Much of the methodology is given over to how one can estimate $\left(k_{\text {ass }} / k_{\text {diss }}\right)$. This quantity may be viewed as a pseudo-equilibrium constant between the energised complexes formed in $\mathrm{A}+\mathrm{B}$ collisions and separated $\mathrm{A}+\mathrm{B}$ and is estimated using the methods of statistical mechanics. It is

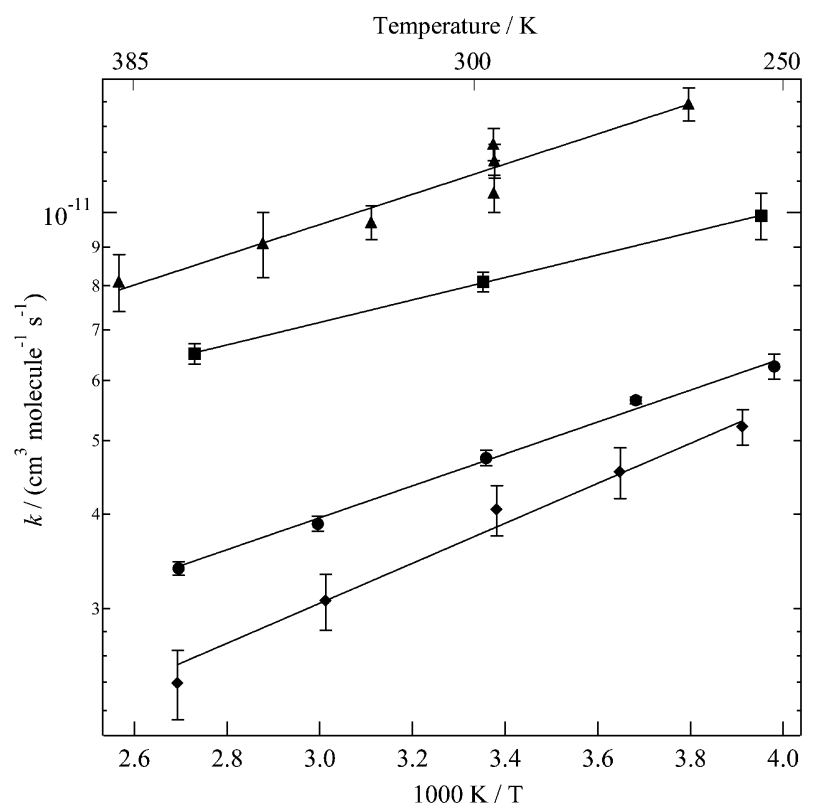

Fig. 3 Values of the rate coefficients for relaxation of $\mathrm{OH}(v=1)$ and $\mathrm{OD}(v=1)$ by $\mathrm{H}_{2} \mathrm{O}$ and $\mathrm{D}_{2} \mathrm{O}$ : triangles $(\boldsymbol{\Delta}), k_{1 \mathrm{a}}$; squares $(\boldsymbol{\square}), k_{4 \mathrm{a}}$; circles $(\bullet), k_{3 \mathrm{a}}$; diamonds $(\bullet), k_{2 \mathrm{a}}$. The solid lines are the Arrhenius fits for each isotopic combination. The parameters yielded by these fits and those from fits to power dependences on temperature are given in Table 5 . assumed that $k_{\mathrm{M}}[\mathrm{M}] \ll k_{\text {diss }}$ and that $(\mathrm{AB})^{*}$ is in a steadystate concentration so that the second-order rate constant for association in the limit of low pressure is simply

$$
k_{2 \text { nd }}^{\circ}=\left(k_{\text {ass }} / k_{\text {diss }}\right) k_{\mathrm{M}}[\mathrm{M}]
$$

Our postulate is that vibrational relaxation via a collision complex can be treated in a similar manner, with $k_{\mathrm{M}}[\mathrm{M}]$ replaced by $k_{\mathrm{IVR}}$; that is, the rate coefficient for transfer of the vibrational quantum originally present in the $\mathrm{O}-\mathrm{H}$ (or $\mathrm{O}-\mathrm{D})$ vibration into the 'bath' of other modes in the complex. Thus, we represent the mechanism for the relaxation of $\mathrm{OH}(v=1)$ by $\mathrm{H}_{2} \mathrm{O}$ with the scheme

$$
\begin{aligned}
\mathrm{OH}(v=1)+\mathrm{H}_{2} \mathrm{O} \underset{k_{\text {diss }}}{\stackrel{k_{\text {ass }}}{\rightleftarrows}}\left\{\mathrm{H}_{2} \mathrm{O}-\mathrm{HO}(v=1)\right\}^{*} \\
\quad \stackrel{k_{\mathrm{IVR}}}{\longrightarrow}\left\{\mathrm{H}_{2} \mathrm{O}-\mathrm{HO}(v=0)\right\}^{* *} \rightarrow \mathrm{OH}(v=0)+\mathrm{H}_{2} \mathrm{O}
\end{aligned}
$$

When $k_{\text {IVR }} \ll k_{\text {diss }} \S$ the second-order rate constant for vibrational relaxation $\left(k_{\text {relax }}\right)$ is

$$
k_{\text {relax }}=\left(k_{\text {ass }} / k_{\text {diss }}\right) k_{\text {IVR }}
$$

We proceed by using the Troe approach ${ }^{32}$ to estimate ( $k_{\text {ass }}$ ) $\left.k_{\text {diss }}\right)$ and then examine the values that $k_{\text {IVR }}$ would have to have to yield the measured values of $k_{\text {relax }}$.

This mechanism does not explicitly include the possibility that an $\mathrm{H}$ (or D) atom exchange occurs. The thermal kinetics of this process have been investigated by Dubey et $a l^{33}$ by measuring rate constants for the isotopic scrambling reactions:

$$
\begin{aligned}
& { }^{18} \mathrm{OH}+\mathrm{H}_{2}^{16} \mathrm{O} \rightarrow{ }^{16} \mathrm{OH}+\mathrm{H}_{2}^{18} \mathrm{O} \text { and } \\
& { }^{16} \mathrm{OD}+\mathrm{H}_{2}^{16} \mathrm{O} \rightarrow{ }^{16} \mathrm{OH}+\mathrm{H}^{16} \mathrm{OD}
\end{aligned}
$$

At $300 \mathrm{~K}$, they found rate constants of $(2.2 \pm 1.0) \times 10^{-16}$ and $(3 \pm 1.0) \times 10^{-16} \mathrm{~cm}^{3}$ molecule $\mathrm{s}^{-1} \mathrm{~s}^{-1}$, respectively, for these two reactions, both four-to-five orders of magnitude smaller than those measured for the vibrational relaxation of $\mathrm{OH}(v=$ 1) and $\operatorname{OD}(v=1)$ in the present work. As long as the energy originally in the $\mathrm{OH}(\mathrm{OD})$ vibrations remains localised in those vibrations, there is no reason to suppose that the rates of these reactions will be accelerated to anything like this extent by excitation of $\mathrm{OH}$ (or OD) to $v=1$. Even when IVR has occurred in the $\mathrm{H}_{2} \mathrm{O}-\mathrm{HO}$ complex, arguments based on RRKM theory would suggest that it is far more likely that dissociation will occur to the original collision partners, rather

$\S$ This appears to be a reasonable assumption, since the rate coefficient that Masgrau et al. ${ }^{18 d}$ estimate for the formation of $\mathrm{H}_{2} \mathrm{O}-\mathrm{HO}$ complexes is $c a$. 30 times greater than the rate coefficient for relaxation of $\mathrm{OH}(v=1)$ by $\mathrm{H}_{2} \mathrm{O}$. 
Table 6 Frequencies $\left(\mathrm{cm}^{-1}\right)$, rotational constants $\left(\mathrm{cm}^{-1}\right)$ and energies $\left(\mathrm{kJ} \mathrm{mol}^{-1}\right)$ for the $\mathrm{H}_{2} \mathrm{O}-\mathrm{HO}$ complex, its isotopomers and fragments at the CISD/cc-pVTZ level

\begin{tabular}{|c|c|c|c|c|c|c|c|c|c|c|c|}
\hline Symmetry & $\mathrm{H}_{2} \mathrm{O}-\mathrm{HO}$ & $\mathrm{H}_{2} \mathrm{O}-\mathrm{DO}$ & $\mathrm{D}_{2} \mathrm{O}-\mathrm{HO}$ & $\mathrm{D}_{2} \mathrm{O}-\mathrm{DO}$ & Symmetry & $\mathrm{H}_{2} \mathrm{O}$ & $\mathrm{H}_{2} \mathrm{O}$ obs $^{b}$ & $\mathrm{D}_{2} \mathrm{O}$ & $\mathrm{OH}$ & $\mathrm{OH}$ obs $^{b}$ & OD \\
\hline$A^{\prime a}$ & 140 & 137 & 105 & 104 & $A_{1}{ }^{a}$ & 1576 & 1595 & 1153 & 3562 & 3568 & 2593 \\
\hline$A^{\prime a}$ & 174 & 172 & 171 & 169 & $A_{1}{ }^{a}$ & 3667 & 3657 & 2644 & & & \\
\hline$A^{\prime a}$ & 415 & 304 & 412 & 299 & $B_{2}{ }^{a}$ & 3760 & 3756 & 2754 & & & \\
\hline$A^{\prime a}$ & 1581 & 1581 & 1158 & 1158 & & & & & & & \\
\hline$A^{\prime a}$ & 3537 & 2575 & 2671 & 2575 & & & & & & & \\
\hline$A^{\prime a}$ & 3706 & 3706 & 3538 & 2671 & & & & & & & \\
\hline$A^{\prime a}$ & 154 & 145 & 116 & 112 & & & & & & & \\
\hline$A^{\prime \prime a}$ & 586 & 448 & 568 & 422 & & & & & & & \\
\hline$A^{\prime \prime}{ }^{a}$ & 3799 & 3799 & 2784 & 2784 & & & & & & & \\
\hline$B^{c}$ & 12.52 & 12.51 & 6.381 & 6.378 & & 27.45 & & 15.27 & 19.05 & & 10.09 \\
\hline$B^{c}$ & 0.2258 & 0.2256 & 0.2084 & 0.2072 & & 14.77 & & 7.392 & & & \\
\hline$B^{c}$ & 0.2237 & 0.2227 & 0.2034 & 0.2023 & & 9.603 & & 4.980 & & & \\
\hline $\mathrm{ZPE}^{d}$ & 84.27 & 76.95 & 68.90 & 61.56 & & 53.84 & & 39.17 & 21.30 & & 15.51 \\
\hline$\Delta \mathrm{ZPE}^{d}$ & -9.14 & -7.60 & -8.43 & -6.88 & & & & & & & \\
\hline$\Delta_{r} H_{0}{ }^{d}$ & -13.99 & -15.52 & -14.70 & -16.24 & & & & & & & \\
\hline$H_{298.15}-\mathrm{H}_{0}{ }^{d}$ & 16.79 & 17.42 & 17.23 & 17.89 & & 9.92 & & 9.97 & 9.24 & & 9.24 \\
\hline$\Delta_{r} H_{298.15}{ }^{d}$ & -16.36 & -17.26 & -16.68 & -17.56 & & & & & & & \\
\hline
\end{tabular}

than over (or through, by tunnelling) the $40-50 \mathrm{~kJ} \mathrm{~mol}^{-1}$ barrier $^{18 d}$ for the internal $\mathrm{H}$-atom transfer and $\mathrm{H}$ (or D) atom scrambling. Finally, we point out that below we only treat the steps in the proposed mechanism up to the point that the IVR has occurred and the complex represented by $\left\{\mathrm{H}_{2} \mathrm{O}-\right.$ $\mathrm{HO}(v=0)\}^{* *}$ has formed.

\section{(a) Ab initio calculations on the hydrogen-bonded $\mathrm{H}_{2} \mathrm{O}-\mathrm{HO}$ system}

In order to be able to estimate ( $k_{\text {ass }} / k_{\text {diss }}$ ) for all four cases of relaxation that we have studied, using Troe's method, new $a b$ initio calculations have been performed on the $\mathrm{H}_{2} \mathrm{O}-\mathrm{HO}$ system. First, the geometry of the lowest energy ${ }^{2} A^{\prime}$ state was obtained using configuration interaction theory with single and double excitations, as used by Xie and Schaefer, ${ }^{18 g}$ applied with the correlation-consistent triple zeta basis set of Dunning. ${ }^{34}$ At this geometry, harmonic vibrational frequencies and rotational constants were calculated for $\mathrm{H}_{2} \mathrm{O}-\mathrm{HO}$ and its various isotopomers. Such calculations overestimate observed fundamental frequencies, largely because they neglect anharmonicity. Based on comparison with the fundamental frequencies of $\mathrm{OH}$ and $\mathrm{H}_{2} \mathrm{O}$, the present CISD/cc-pVTZ results were scaled by a factor of 0.9323 , which reproduced the experimental values of the frequencies to within $20 \mathrm{~cm}^{-1} .35$ The scaled results for the complexes are given in Table 6 . These calculations were carried out with the Gaussian 03 suite of programs. ${ }^{36}$

Next, an improved geometry was obtained using coupled cluster theory, with single, double and perturbatively-estimated triple excitations, with the augmented cc-pVTZ basis set. ${ }^{34,37}$ The Molpro program suite was used to implement spin-unrestricted CCSD(T) theory based on a restricted Hartree-Fock wavefunction. ${ }^{38}$ The $\mathrm{T} 1$ diagnostic was 0.009 , which confirms the applicability of this correlated method based on a single-reference wavefunction. ${ }^{39}$ The $\operatorname{CCSD}(\mathrm{T}) /$
aug-cc-pVTZ geometry is shown in Fig. 4. The energy at this geometry (and for $\mathrm{OH}$ and $\mathrm{H}_{2} \mathrm{O}$ at their corresponding geometries) was evaluated with $\operatorname{CCSD}(\mathrm{T})$ theory with the basis set sequence aug-cc-pVDZ, aug-cc-pVTZ and aug-ccpVQZ (see Table 7), which enables a systematic extrapolation of the energy, via an empirical exponential function, to the infinite or complete basis set (CBS) limit. ${ }^{40}$ These energy differences were combined, along with corrections for spin-orbit splitting in $\mathrm{OH}$ and the complex (139 and $200 \mathrm{~cm}^{-1}$, respectively ${ }^{15,35}$ ), and for changes in zero-point vibrational energy, to obtain the $0 \mathrm{~K}$ bond dissociation enthalpy $\Delta H_{0}=$ $D_{0}$ between the adduct and separated fragments. The binding enthalpy at $298.15 \mathrm{~K}, \Delta_{\mathrm{r}} H_{298.15}$, was obtained via enthalpy corrections based on the computed frequencies (assuming harmonic behaviour) and the experimental spin-orbit splittings noted above.

\section{(b) Computational results}

The $\operatorname{CCSD}(\mathrm{T})$ equilibrium geometry shown in Fig. 4 is very similar to that calculated by Ohshima et al. ${ }^{14}$ with a hydrogen bond length of $1.910 \times 10^{-10} \mathrm{~m}$. Our calculated bond length can also be compared with that obtained by Brauer et al. ${ }^{15}$ via an analysis of their Fourier transform microwave spectrum, $1.952 \times 10^{-10} \mathrm{~m}$. The latter quantity should, of course, be

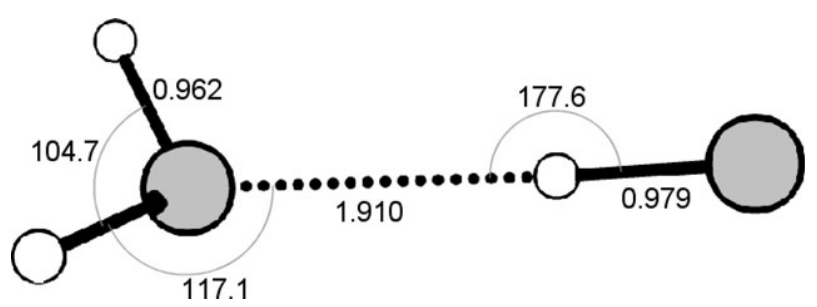

Fig. 4 Geometry of the lowest-lying ${ }^{2} A^{\prime}$ hydrogen-bonded complex between $\mathrm{H}_{2} \mathrm{O}$ and $\mathrm{OH}$ computed at the $\operatorname{CCSD}(\mathrm{T}) /$ aug-cc-pVTZ level. 
Table 7 Energies calculated at the coupled cluster level ${ }^{a}$

\begin{tabular}{lcrrr}
\hline Species & Aug-cc-pVDZ & Aug-cc-pVTZ & Aug-cc-pVQZ & \multicolumn{1}{c}{ CBS } \\
\hline $\mathrm{OH}$ & -75.584019 & -75.645547 & -75.664444 & -75.672821 \\
$\mathrm{H}_{2} \mathrm{O}$ & -76.273859 & -76.342326 & -76.363574 & -16.373136 \\
$\mathrm{H}_{2} \mathrm{O}-\mathrm{HO}$ & -151.867236 & -151.997256 & -152.037282 & -152.055084 \\
$\Delta E / \mathrm{kJ} \mathrm{mol}^{-1 b}$ & -24.57 & -24.64 & -24.32 & -23.96
\end{tabular}

${ }^{a} \mathrm{RCCSD}(\mathrm{T}) / \mathrm{UHF}$ energies obtained with different basis sets at the $\operatorname{CCSD}(\mathrm{T}) /$ aug-cc-pVTZ geometry, and the extrapolation to the complete basis set limit, in au $\left(1 \mathrm{au} \approx 2625.5 \mathrm{~kJ} \mathrm{~mol}^{-1}\right) .{ }^{b}$ Energy difference between the $\mathrm{H}_{2} \mathrm{O}$-complex and the separated fragments $\mathrm{H}_{2} \mathrm{O}+\mathrm{HO}($ excluding $\mathrm{ZPE}$ and spin-orbit corrections, see text).

larger because of vibrational averaging over the anharmonic stretching motion, and also because the very low lying $A^{\prime \prime}$ state, for which we compute a $\operatorname{CCSD}(\mathrm{T})$ hydrogen bond length of $1.938 \times 10^{-10} \mathrm{~m}$, may be significantly populated. The CBS extrapolation employed here eliminates any influence of basis set superposition error on the energy, which would lead to overestimated binding energies for theoretical methods based on moderate-sized basis sets. In fact the CCSD(T) dissociation energy with the three correlation consistent basis sets changed by less than about $1 \mathrm{~kJ} \mathrm{~mol}^{-1}$ (see Table 7), which indicates that good convergence has been achieved. As has been noted previously, ${ }^{15}$ the angular momentum of the two spin-orbit states, ${ }^{2} \Pi_{1 / 2}$ and ${ }^{2} \Pi_{3 / 2}$, of $\mathrm{OH}$ persists in the adduct to yield the ${ }^{2} A^{\prime}$ ground state and a low-lying ${ }^{2} A^{\prime \prime}$ state. The latter two are resolved as distinct states by standard non-relativistic computational methods, but the two states of $\mathrm{OH}$ are not. Consistent treatment of reactants and products, i.e., correction of the energy of $\mathrm{OH}$ by half the spin-orbit splitting, lowers the calculated dissociation energy by $c a .0 .8 \mathrm{~kJ} \mathrm{~mol}^{-1}$. While small, this effect also contributes to previous values of $D_{0}$ falling higher than our best estimate of $14.0 \mathrm{~kJ} \mathrm{~mol}^{-1}$ (see Table 6). The contributions of electronic degeneracy to $H_{298}-H_{0}$ fortuitously cancel between reactants and adduct to within $c a .0 .1 \mathrm{~kJ} \mathrm{~mol}^{-1}$. Harmonic treatment of low-frequency modes is questionable, but with this simplification we derive $\Delta_{\mathrm{r}} H_{298.15}=-16.4 \mathrm{~kJ} \mathrm{~mol}^{-1}$. This is at the positive end of previous estimates, but it appears to be the most reliable value to date.

\section{(c) Estimates of the rates of relaxation}

Troe's method ${ }^{32}$ for estimating $\left(k_{\text {ass }} / k_{\text {diss }}\right)$ proceeds in stages. First, one makes an initial estimate of this pseudo-equilibrium constant between $\mathrm{A}+\mathrm{B}$ and $\mathrm{AB}^{*}$ by calculating a density of harmonic vibrational states $\left(\rho_{\mathrm{vib}, \mathrm{h}}\left(E_{0}\right)\right)$ for a rotationless $($ i.e., $J=0) \mathrm{AB}^{*}$ energised complex at the dissociation energy $\left(E_{0}\right)$ of $\mathrm{AB}$ (see eqn (4.4b) in ref. 32). The first two lines of each block of Table 8 lists values of $\rho_{\mathrm{vib}, \mathrm{h}}\left(E_{0}\right) k T$ and values of $\left(k_{\mathrm{ass}} /\right.$ $\left.k_{\text {diss }}\right)_{E_{0}, J=0}$. In applying this method to estimating values of $\left(k_{\mathrm{ass}} / k_{\mathrm{diss}}\right)_{E_{0}, J=0}$ for the four isotopically different cases, (1a), (2a), (3a) and (4a), of interest here, we have assumed that only the five low frequency modes in the complexes (see Table 6) are 'active'; that is, contribute to the density of vibrational states. The energies $\left(E_{0}\right)$ at which we have calculated the harmonic density of states, via eqn (4.4b) in ref. 32, are those given as $-\Delta_{r} H_{0}$ in Table 6. It is noticeable that isotopic substitution changes the densities of harmonic vibrational states in the complexes as one would expect as deuterium is substituted for hydrogen. However, as the values of $\left(k_{\text {ass }} / k_{\text {diss }}\right)_{E_{0}}, J=0$ show, these changes are largely cancelled by corresponding changes in the partition functions of the 'reagents', $\mathrm{OH}(\mathrm{OD})$ and $\mathrm{H}_{2} \mathrm{O}$ $\left(\mathrm{D}_{2} \mathrm{O}\right)$.

Next, in Troe's prescription, one applies various corrections for factors omitted in the first estimate of $\left(k_{\mathrm{ass}} / k_{\mathrm{diss}}\right)$ : (a) anharmonicity ( $F_{\text {anh }}$, see eqn (5.4) in ref. 32), (b) the spread of internal energies in $\mathrm{AB}^{*}$ complexes formed in thermal collisions between $\mathrm{A}$ and $\mathrm{B}$ ( $F_{\mathrm{E}}$, see eqn (6.3) in ref. 32), and (c) the neglect of effects due to overall rotation ( $F_{\text {rot }}$, see eqn (7.24) in ref. 32). These multiplicative factors all increase the estimates of $\left(k_{\text {ass }} / k_{\text {diss }}\right)$ and yield the final estimates given in the third row of each block of Table 8. The measured rate constants for relaxation have then been divided by these results to obtain estimates of $k_{\mathrm{IVR}}$.

A number of things are worthy of note: (i) for a given molecular system, the estimated values of $k_{\mathrm{IVR}}$ are reasonably independent of temperature, as one might expect; (ii) the observed temperature-dependences of $k_{\text {relax }}$ are matched quite well by those of $\left(k_{\text {ass }} / k_{\text {diss }}\right)$, giving some support to the hypothesis that relaxation in these cases is occurring via the

Table 8 Estimates of rate coefficients for intramolecular vibrational relaxation within the $\mathrm{H}_{2} \mathrm{O}$-complex and its isotopomers

\begin{tabular}{|c|c|c|c|}
\hline & $200 \mathrm{~K}$ & $300 \mathrm{~K}$ & $400 \mathrm{~K}$ \\
\hline \multicolumn{4}{|l|}{$\mathrm{OH}+\mathrm{H}_{2} \mathrm{O}$} \\
\hline$\rho_{\text {vib,h }}\left(E_{0}\right) k T$ & 72.7 & 109.0 & 145.3 \\
\hline$\left(k_{\mathrm{ass}} / k_{\mathrm{diss}}\right)_{E_{0}, J=0} / \mathrm{cm}^{3}$ & $5.2 \times 10^{-23}$ & $2.85 \times 10^{-23}$ & $1.85 \times 10^{-2 .}$ \\
\hline$\left(k_{\text {ass }} / k_{\mathrm{diss}}\right) / \mathrm{cm}^{3}$ & $4.3 \times 10^{-22}$ & $1.72 \times 10^{-22}$ & $9.6 \times 10^{-23}$ \\
\hline$k_{\text {relax }}(v=1) / \mathrm{cm}^{3} \mathrm{~s}^{-1}$ & $2.07 \times 10^{-11}$ & $1.14 \times 10^{-11}$ & $0.65 \times 10^{-11}$ \\
\hline \multicolumn{4}{|l|}{$\mathrm{OH}+\mathrm{D}_{2} \mathrm{O}$} \\
\hline$\rho_{\mathrm{vib}, \mathrm{h}}\left(E_{0}\right) k T$ & 139.7 & 209.6 & 279.4 \\
\hline$\left(k_{\mathrm{ass}} / k_{\mathrm{diss}}\right)_{E_{0}, J=0} / \mathrm{cm}^{3}$ & $5.9 \times 10^{-23}$ & $3.0 \times 10^{-23}$ & $1.93 \times 10^{-23}$ \\
\hline$\left(k_{\text {ass }} k_{\text {diss }}\right) / \mathrm{cm}^{3}$ & $4.9 \times 10^{-22}$ & $1.82 \times 10^{-22}$ & $1.0 \times 10^{-22}$ \\
\hline$k_{\text {relax }}(v=1) / \mathrm{cm}^{3} \mathrm{~s}^{-1}$ & $8.7 \times 10^{-12}$ & $3.8 \times 10^{-12}$ & $2.1 \times 10^{-12}$ \\
\hline$k_{\mathrm{IVR} / \mathrm{s}^{-1}}$ & $1.8 \times 10^{10}$ & $2.1 \times 10^{10}$ & $2.1 \times 10^{10}$ \\
\hline \multicolumn{4}{|l|}{$\mathrm{OD}+\mathrm{H}_{2} \mathrm{O}$} \\
\hline$\rho_{\mathrm{vib}, \mathrm{h}}\left(E_{0}\right) k T$ & 149.5 & 224.3 & 299.1 \\
\hline$\left(k_{\mathrm{ass}} / k_{\mathrm{diss}}\right)_{E_{0}, J=0} / \mathrm{cm}^{3}$ & $5.0 \times 10^{-23}$ & $3.0 \times 10^{-23}$ & $1.97 \times 10^{-2}$ \\
\hline$\left(k_{\mathrm{ass}} / k_{\mathrm{diss}}\right) / \mathrm{cm}^{3}$ & $4.6 \times 10^{-22}$ & $1.64 \times 10^{-22}$ & $1.02 \times 10^{-22}$ \\
\hline$k_{\text {relax }}(v=1) / \mathrm{cm}^{3} \mathrm{~s}^{-1}$ & $7.4 \times 10^{-12}$ & $4.7 \times 10^{-12}$ & $2.95 \times 10^{-12}$ \\
\hline$k_{\mathrm{IVR}} / \mathrm{s}^{-1}$ & $1.6 \times 10^{10}$ & $2.9 \times 10^{10}$ & $2.9 \times 10^{10}$ \\
\hline \multicolumn{4}{|l|}{$\mathbf{O D}+\mathbf{D}_{\mathbf{2}} \mathbf{O}$} \\
\hline$\rho_{\mathrm{vib}, \mathrm{h}}\left(E_{0}\right) k T$ & 287.7 & 431.6 & 575.5 \\
\hline$\left(k_{\text {ass }} k_{\text {diss }}\right)_{E_{0}, J=0} / \mathrm{cm}^{3}$ & $5.8 \times 10^{-23}$ & $3.15 \times 10^{-23}$ & $2.1 \times 10^{-23}$ \\
\hline$\left(k_{\mathrm{ass}} / k_{\mathrm{diss}}\right) / \mathrm{cm}^{3}$ & $4.9 \times 10^{-22}$ & $1.94 \times 10^{-22}$ & $1.09 \times 10^{-22}$ \\
\hline$k_{\text {relax }}(v=1) / \mathrm{cm}^{3} \mathrm{~s}^{-1}$ & $1.3 \times 10^{-11}$ & $8.1 \times 10^{-12}$ & $5.9 \times 10^{-12}$ \\
\hline$k_{\mathrm{IVR}} / \mathrm{s}^{-1}$ & $2.7 \times 10^{16}$ & $4.2 \times 10^{10}$ & $5.4 \times 10^{10}$ \\
\hline
\end{tabular}


transient formation of hydrogen-bonded complexes; (iii) there are significant differences between the values of $k_{\mathrm{IVR}}$ for different molecular systems with those for the 'like-isotope' pairs, $\mathrm{OH}+\mathrm{H}_{2} \mathrm{O}$ and $\mathrm{OD}+\mathrm{D}_{2} \mathrm{O}$, being somewhat larger than those for the 'unlike-isotope' pairs, $\mathrm{OH}+\mathrm{D}_{2} \mathrm{O}$ and $\mathrm{OD}+\mathrm{H}_{2} \mathrm{O}$. These differences are discussed further in the next section.

\section{Discussion and conclusions}

Reactions of $\mathrm{O}\left({ }^{1} \mathrm{D}\right)$ were used to produce vibrationally excited $\mathrm{OH}$ and $\mathrm{OD}$ for all of the measurements on processes $(2 \mathrm{a}, 2 \mathrm{~b})$, $(3 a, 3 b)$ and $(4 a, 4 b)$, and for two of the measurements on (1a). As discussed previously, when reactions of $\mathrm{O}\left({ }^{1} \mathrm{D}\right)$ are used to generate vibrationally excited $\mathrm{OH}$ (OD) significant errors may arise in the derived rate coefficients, because fits to the traces of LIF signals of $\mathrm{OH}(v=1)$ and $\mathrm{OD}(v=1)$ may be affected by $\mathrm{OH}$ and OD cascading down from higher levels into $(v=1)$. These effects have been estimated, via simple numeric modelling of the kinetics, to cause a potential error of $c a .8 \%$ when $\mathrm{O}\left({ }^{1} \mathrm{D}\right)+\mathrm{H}_{2} \mathrm{O}$ is employed to generate vibrationally excited $\mathrm{OH}$. In this regard, the good agreement between the derived rate coefficients for relaxation of $\mathrm{OH}(v=1)$ by $\mathrm{H}_{2} \mathrm{O}$ using different sources of vibrationally excited $\mathrm{OH}$ is reassuring. The potential errors for the rate coefficients for the relaxation of $\mathrm{OH}(v=1)$ by $\mathrm{D}_{2} \mathrm{O}$ are similar.

The errors in the rate coefficients for removal of $\operatorname{OD}(v=1)$ are larger than those for removal of $\mathrm{OH}(v=1)$ because reactions of $\mathrm{O}\left({ }^{1} \mathrm{D}\right)$ can produce $\mathrm{OD}$ in higher vibrational states, due to the closer spacing of the OD vibrational levels, and because the vibrational distribution of OD produced by these reactions is less well characterized than the vibrational distribution of $\mathrm{OH}$ produced by $\mathrm{O}\left({ }^{1} \mathrm{D}\right)$ reactions. In the case of $\mathrm{OH}(v=1)+\mathrm{D}_{2} \mathrm{O}$, the complication arising from 'cascading' is exacerbated because the corresponding rate coefficient for removal of $\operatorname{OD}(v=2)$ is only a factor of 1.6 larger than that for relaxation of $\mathrm{OD}(v=1)$. This makes the temporal profiles of $\mathrm{OD}(v=1)$ quite difficult to fit. Thus, our measured rate coefficients for removal of $\mathrm{OD}(v=1)$ by $\mathrm{H}_{2} \mathrm{O}$ and $\mathrm{D}_{2} \mathrm{O}$ have errors of up to 20 and $30 \%$, respectively, due to this effect.

Next, we compare our results with those obtained, many years ago, on the relaxation of $\mathrm{HF}(v=1)$ by $\mathrm{H}_{2} \mathrm{O}$ and $\mathrm{D}_{2} \mathrm{O}$. Unfortunately, only room temperature measurements are available for these systems and there are no data on the corresponding $\mathrm{DF}(v=1)+\mathrm{H}_{2} \mathrm{O}, \mathrm{D}_{2} \mathrm{O}$ systems. For both $\mathrm{HF}(v=1)+\mathrm{H}_{2} \mathrm{O}$ and $\mathrm{HF}(v=1)+\mathrm{D}_{2} \mathrm{O}$, Hancock and Green ${ }^{9}$ determined a relaxation rate coefficient of $1.25 \times 10^{-10}$ $\mathrm{cm}^{3}$ molecule $\mathrm{s}^{-1} \mathrm{~s}^{-1}$ and the result for $\mathrm{HF}(v=1)+\mathrm{H}_{2} \mathrm{O}$ was supported by Frost et al. ${ }^{11}$ who reported an identical value of the rate coefficient. A comparison between the vibrational relaxation of $\mathrm{OH}$ and $\mathrm{HF}$ is interesting because of the similarities between the two species. Thus, the $v=1 \rightarrow v=0$ vibrational transition energy in $\mathrm{HF}$ is equivalent to 3958.4 $\mathrm{cm}^{-1}$ (in $\mathrm{OH}$ it is $3569.6 \mathrm{~cm}^{-1}$ ) and $\mathrm{HF}$ has a dipole moment of $1.826 \mathrm{D}(\mathrm{OH}: 1.668 \mathrm{D}) .{ }^{26}$ However, the dissociation energy of the hydrogen bond in $\mathrm{H}_{2} \mathrm{O}-\mathrm{HF}$ is given ${ }^{41}$ as $D_{\mathrm{e}}=42.9 \mathrm{~kJ}$ $\mathrm{mol}^{-1}$ and $D_{0}=34.3 \mathrm{~kJ} \mathrm{~mol}^{-1}$, values that are significantly larger than the corresponding quantities for $\mathrm{H}_{2} \mathrm{O}-\mathrm{HO}$ (see
Tables 1 and 6). It seems reasonable to suppose that relaxation in both these systems is facilitated by the transient formation of hydrogen-bonded complexes. However, the more strongly bound $\mathrm{H}_{2} \mathrm{O}-\mathrm{HF}$ complex probably survives long enough with respect to re-dissociation to $\mathrm{H}_{2} \mathrm{O}+\mathrm{HF}(v=1)$ to allow most of the complexes to undergo IVR with the result that the rate coefficient for relaxation is closer to that for formation of the complexes than in the case of $\mathrm{H}_{2} \mathrm{O}+\mathrm{OH}(v=1)$.

A second useful comparison is with our earlier results on the relaxation of $\mathrm{OH}(v=1)$ and $\mathrm{OD}(v=1)$ by $\mathrm{HNO}_{3}$ and $\mathrm{DNO}_{3}{ }^{12}{ }^{12}$ Those previous results are similar to those reported in the present paper in three respects. Firstly, the rate coefficients at $298 \mathrm{~K}$ for the relaxation of $\mathrm{OH}(v=1)$ by $\mathrm{HNO}_{3}$, of $\mathrm{OH}(v=1)$ by $\mathrm{DNO}_{3}$, of $\mathrm{OD}(v=1)$ by $\mathrm{HNO}_{3}$ and $\mathrm{OD}(v=1)$ by $\mathrm{DNO}_{3}$ are factors of 2.0, 1.5, 1.6 and 2.2 larger than those shown in Table 5 for the corresponding relaxation process in the $\mathrm{OH}(v=1), \mathrm{OD}(v=1)+\mathrm{H}_{2} \mathrm{O}, \mathrm{D}_{2} \mathrm{O}$ system. Secondly, as the numbers in the previous sentence indicate, the relative values of the rate coefficients for different isotopic pairs are rather similar. Thirdly, the temperature dependences of the two sets of rate constants are also similar. Thus, the values of the parameter $n$ given in the last column of Table $5(1.47,2.04$, 1.63 and 1.14) can be compared with those of 1.8, 2.6, 2.4 and 2.2 for the relaxation of $\mathrm{OH}(v=1)$ by $\mathrm{HNO}_{3}$, of $\mathrm{OH}(v=1)$ by $\mathrm{DNO}_{3}$, of $\mathrm{OD}(v=1)$ by $\mathrm{HNO}_{3}$ and of $\mathrm{OD}(v=1)$ by $\mathrm{DNO}_{3}$, respectively.

We have argued in the previous section that the large values of the rate coefficients for relaxation of $\mathrm{OH}(v=1)$ and $\mathrm{OD}(v=1)$ in collisions with $\mathrm{H}_{2} \mathrm{O}$ and $\mathrm{D}_{2} \mathrm{O}$ and the rather strong negative dependence of these rate coefficients on temperature are at the very least consistent with relaxation via transient hydrogen-bonded complexes, such as $\mathrm{H}_{2} \mathrm{O}-\mathrm{HO}$. In the two cases of $\mathrm{OH}(v=1)+\mathrm{H}_{2} \mathrm{O}$ and $\mathrm{OD}(v=1)+\mathrm{D}_{2} \mathrm{O}$, it is possible that vibrational relaxation occurs, without the formation of weakly-bound complexes, by near-resonant vibration-vibration ( $\mathrm{V}-\mathrm{V})$ energy exchange in direct collisions; that is,

$$
\begin{gathered}
\mathrm{OH}(v=1)+\mathrm{H}_{2} \mathrm{O} \rightarrow \mathrm{OH}(v=0)+\mathrm{H}_{2} \mathrm{O}\left(v_{1} \text { or } v_{3}\right) \\
\left(\Delta E / h c=+87 \text { or } 186 \mathrm{~cm}^{-1}\right) \\
\mathrm{OD}(v=1)+\mathrm{D}_{2} \mathrm{O} \rightarrow \mathrm{OD}(v=0)+\mathrm{D}_{2} \mathrm{O}\left(v_{1} \text { or } v_{3}\right) \\
\left(\Delta E / h c=+39 \text { or } 157 \mathrm{~cm}^{-1}\right)
\end{gathered}
$$

However, for $\mathrm{OH}(v=1)+\mathrm{D}_{2} \mathrm{O}$ and $\mathrm{OD}(v=1)+\mathrm{H}_{2} \mathrm{O}$, any vibrational exchange channels involving single quantum transitions in $\mathrm{D}_{2} \mathrm{O}$ and $\mathrm{H}_{2} \mathrm{O}$ are far from resonant and, in the second case, also strongly endothermic. Given that relaxation remains rapid even in these cases, it seems that relaxation via hydrogen-bonded complexes is the most likely mechanism in all four cases. This is consistent with the similarity of the temperature-dependence for all four processes which, in the Troe-type calculations that we have presented, is attributable to the temperature-dependence of the factor $\left(k_{\mathrm{ass}} / k_{\mathrm{diss}}\right)$ and depends, in turn, on the strong dependence of $k_{\text {diss }}$ on the internal energy of the complex. If $\mathrm{V}-\mathrm{V}$ energy exchange in direct collisions was contributing significantly to the relaxation in processes (1a) and (4a), we would expect their rate 
coefficients to have a noticeably smaller temperature-dependence than those for the slower, non-resonant processes (2a) and (3a). This is not what we observe.

At ca. $298 \mathrm{~K}$, the rate constants for relaxation of $\mathrm{OH}(v=2)$ by $\mathrm{D}_{2} \mathrm{O}$, of $\mathrm{OD}(v=2)$ by $\mathrm{H}_{2} \mathrm{O}$ and of $\mathrm{OD}(v=2)$ by $\mathrm{D}_{2} \mathrm{O}$ (see Table 3) are factors of $c a$. 3.9, 3.0 and 1.6, respectively, larger than the corresponding rate coefficients for relaxation of $\mathrm{OH}(v=1)$ and $\mathrm{OD}(v=1)$. This acceleration probably reflects a faster rate of IVR as a result of the increased excitation and anharmonicity in the $\mathrm{OH}(\mathrm{OD})$ vibration.

The calculations presented in the previous section suggest that, although the rates of IVR are similar in all the isotopically different systems that we have studied, $k_{\text {IVR }}$ for $\mathrm{H}_{2} \mathrm{O}-\mathrm{HO}$ $(v=1)>k_{\mathrm{IVR}}$ for $\mathrm{D}_{2} \mathrm{O}-\mathrm{DO}(v=1)>k_{\mathrm{IVR}}$ for $\mathrm{H}_{2} \mathrm{O}-\mathrm{DO}$ $(v=1) \approx k_{\mathrm{IVR}}$ for $\mathrm{D}_{2} \mathrm{O}-\mathrm{HO}(v=1)$. This ordering indicates that IVR is (slightly) favoured in isotopically 'non-mixed' systems, an effect that may reflect the possibility of nearresonant vibrational energy exchange within the $\mathrm{H}_{2} \mathrm{O}-\mathrm{HO}$ $(v=1)$ and $\mathrm{D}_{2} \mathrm{O}-\mathrm{DO}(v=1)$ complexes. Alternatively, it might result from some participation of the direct near-resonant V-V processes represented by processes (5) and (6).

The only direct measurements of IVR rates in complexes involving $\mathrm{OH}(v>0)$ are those of Lester and her coworkers. $^{42-44}$ They generate weakly bound complexes in low temperature jet expansions and perform vibrational action spectroscopy to characterise the structure and dynamics of these species. They have not carried out experiments on the hydrogen-bonded complexes formed between $\mathrm{OH}$ radicals and $\mathrm{H}_{2} \mathrm{O}$. The only hydrogen-bonded complexes whose dynamics they have investigated are those formed between $\mathrm{OH}$ and $\mathrm{CO}^{42}$ (and OD + OC) ${ }^{43}$ and $\mathrm{OH}$ and $\mathrm{C}_{2} \mathrm{H}_{2} \cdot{ }^{44}$ Their experiments can measure vibrational predissociation lifetimes $<0.15 \mathrm{~ns}$, from observations of spectroscopic linewidths, or $>5 \mathrm{~ns}$ from direct time-domain measurements. It appears that the time scale for the overall decay of the $\mathrm{OH}(v=2)-\mathrm{OC}$ complexes ${ }^{42 b}$ lies between these values. In comparing IVR rates inferred from our experiments and those determined from Lester's experiments one should bear in mind that the complexes in her group's experiments are internally 'cold', apart from the specific excitation of the OH (OD) stretch, whereas the complexes formed in collisions, as in our experiments, will have energy released into the low frequency vibrational modes of the complex as a consequence of the formation of the hydrogen bond.

To summarise, we have measured rate coefficients for the vibrational relaxation of $\mathrm{OH}(v=1)$ and $\mathrm{OD}(v=1)$ by $\mathrm{H}_{2} \mathrm{O}$ and $\mathrm{D}_{2} \mathrm{O}$ at temperatures between 251 and $390 \mathrm{~K}$, and for the vibrational relaxation of $\mathrm{OH}(v=2)$ by $\mathrm{D}_{2} \mathrm{O}$ and $\mathrm{OD}(v=2)$ by $\mathrm{H}_{2} \mathrm{O}$ and $\mathrm{D}_{2} \mathrm{O}$ at $c a .298 \mathrm{~K}$. On the bases of the magnitude of the rate coefficients for relaxation of $\mathrm{OH}(v=1)$ and $\mathrm{OD}(v=1)$ and their temperature-dependence, we propose that relaxation involves the transient formation of hydrogenbonded complexes which can undergo intramolecular vibrational redistribution at a rate competitive with their re-dissociation. We have modelled this process for the isotopically different systems using the results of new ab initio calculations and a method, due to Troe, for treating processes that proceed via complex formation. These calculations suggest that the measured rates of relaxation will be reproduced if the rate coefficients for IVR range from $c a .8 \times 10^{10} \mathrm{~s}^{-1}$ in the $\mathrm{H}_{2} \mathrm{O}-\mathrm{HO}(v=1)$ complex to $c a .2 \times 10^{10} \mathrm{~s}^{-1}$ in the $\mathrm{D}_{2} \mathrm{O}-\mathrm{HO}(v=1)$ complex.

\section{Acknowledgements}

This work in Boulder was funded in part by the NASA Upper Atmosphere Program. D.C.M. acknowledges an NSF graduate research fellowship. P.M. thanks the R. A. Welch Foundation (Grant B-1174), the UNT Faculty Research Fund and the National Center for Supercomputing Applications (Grant CHE000015N) for support.

\section{References}

1 J. T. Yardley, Introduction to Molecular Energy Transfer, Academic Press, New York, 1980.

2 (a) K. Glänzer and J. Troe, J. Chem. Phys., 1975, 63, 4352; (b) M. Quack and J. Troe, Ber. Bunsen-Ges. Phys. Chem., 1977, 81, 160; (c) R. P. Fernando and I. W. M. Smith, Chem. Phys. Lett., 1979, 66, 218; (d) R. P. Fernando and I. W. M. Smith, J. Chem. Soc., Faraday Trans. 2, 1981, 77, 459.

3 I. W. M. Smith and M. D. Williams, J. Chem. Soc., Faraday Trans. 2, 1985, 81, 1849.

4 L. D'Ottone, D. Bauer, P. Campuzano-Jost, M. Fardy and A. J. Hynes, Faraday Discuss., 2005, 130, 111.

5 J. Brunning, D. W. Derbyshire, I. W. M. Smith and M. D. Williams, J. Chem. Soc., Faraday Trans. 2, 1988, 84, 105.

6 M. A. Blitz, K. J. Hughes and M. J. Pilling, J. Phys. Chem. A, 2003, 107, 1971 .

7 I. W. M. Smith, J. Chem. Soc., Faraday Trans., 1997, 93, 3741.

8 (a) J. F. Bott and N. Cohen, J. Chem. Phys., 1973, 58, 4539; (b) J. F. Bott and N. Cohen, J. Chem. Phys., 1974, 61, 681.

9 J. K. Hancock and W. H. Green, J. Chem. Phys., 1972, 57, 4515.

10 J. A. Blauer, W. C. Solomon, L. H. Sentman and T. W. Owen, J. Chem. Phys., 1972, 57, 3277.

11 R. J. Frost, D. S. Green, M. K. Osborn and I. W. M. Smith, Int. J. Chem. Kinet., 1986, 18, 885.

12 D. C. McCabe, S. S. Brown, M. K. Gilles, R. K. Talukdar, I. W. M. Smith and A. R. Ravishankara, J. Phys. Chem. A, 2003, 107, 7762.

13 S. S. Brown, J. B. Burkholder, R. K. Talukdar and A. R. Ravishankara, J. Phys. Chem. A, 2001, 105, 1605.

14 Y. Ohshima, K. Sato, Y. Sumiyoshi and Y. Endo, J. Am. Chem. Soc., 2005, 127, 1108.

15 C. S Brauer, G. Sedo, E. M. Grumstrup, K. R. Leopold, M. D. Marshall and H. O. Leung, Chem. Phys. Lett., 2005, 401, 420.

16 (a) V. S. Langford, A. J. McKinley and T. I. Quickenden, J. Am. Chem. Soc., 2000, 122, 12859; (b) P. D. Cooper, H. G. Kjaergaard, V. S. Langford, A. J. McKinley, T. I. Quickenden and D. P. Schofield, J. Am. Chem. Soc., 2003, 125, 6048.

17 (a) H. J. Deyerl, A. K. Luong, T. G. Clements and R. E. Continetti, Faraday Discuss., 2000, 115, 147; (b) D. W. Arnold, C. Xu and D. M. Neumark, J. Chem. Phys., 1995, 102, 6088.

18 (a) H. Basch and S. Hoz, J. Phys. Chem. A, 1997, 101, 4416; (b) M. R. Hand, C. F. Rodriquez, I. H. Williams and G. G. BalintKurti, J. Phys. Chem. A, 1998, 102, 5958; (c) K. S. Kim, H. S. Kim, J. H. Jang, B. J. Mhin, Y. M. Xie and H. F. Schaefer, J. Chem. Phys., 1991, 94, 2057; (d) L. Masgrau, A. Gonzalez-Lafont and J. M. Lluch, J. Phys. Chem. A, 1999, 103, 1044; (e) T. Uchimaru, A. K. Chandra, S. Tsuzuki, M. Sugie and A. Sekiya, J. Comput. Chem., 2003, 24, 1538; (f) B. Wang, H. Hou and Y. Gu, Chem. Phys. Lett., 1999, 303, 96; (g) Y. Xie and H. F. Schaefer, J. Chem. Phys., 1993, 98, 8829; (h) Z. Zhou, Y. Qu, A. Fu, B. Du, F. He and H. Gao, Int. J. Quantum Chem., 2002, 89, 550.

19 S. Aloisio and J. S. Francisco, Acc. Chem. Res., 2000, 33, 825.

20 G. L. Vaghjiani and A. R. Ravishankara, J. Phys. Chem., 1989, 93, 1948.

21 G. Ondrey, N. van Veen and R. Bersohn, J. Chem. Phys., 1983, 78, 3732. 
22 E. Silvente, R. C. Richter and A. J. Hynes, J. Chem. Soc., Faraday Trans., 1997, 93, 2821.

23 (a) K.-H. Gericke, F. J. Comes and R. D. Levine, J. Chem. Phys., 1981, 74, 6106; (b) C. B. Cleveland and J. R. Wiesenfeld, J. Chem. Phys., 1992, 96, 248.

24 (a) P. M. Aker, J. J. A. O'Brien and J. J. Sloan, J. Chem. Phys., 1986, 84, 745; (b) S. G. Cheskis, A. A. Iogansen, P. V. Kulakov, I. Y. Razuvaev, O. M. Sarkisov and A. A. Titov, Chem. Phys. Lett., 1989, 155, 37; (c) C. R. Park and J. R. Wiesenfeld, J. Chem. Phys., 1991, 95, 8166.

25 W. A. Guillory, K. H. Gericke and F. J. Comes, J. Chem. Phys., $1983,78,5993$.

26 CRC Handbook of Chemistry and Physics, CRC Press, Boca Raton, FL, 1989.

27 A. H. Harvey and E. W. Lemmon, J. Phys. Chem. Ref. Data, 2002, 31, 173.

28 W. Wagner, A. Saul and A. Pruss, J. Phys. Chem. Ref. Data, 1994, 23, 515 .

29 W. A. Van Hook, J. Phys. Chem., 1968, 72, 1234.

30 D. C. McCabe, PhD thesis, University of Colorado, Boulder, 2004.

31 (a) J. D. Bradshaw, M. O. Rodgers and D. D. Davis, Appl. Opt., 1984, 23, 2134; (b) G. P. Glass, H. Endo and B. K. Chaturvedi, J. Chem. Phys., 1982, 77, 5450; (c) G. A. Raiche, J. B. Jeffries, K. J. Rensberger and D. R. Crosley, J. Chem. Phys., 1990, 92, 7258; (d) J. E. Spencer and G. P. Glass, Int. J. Chem. Kinet., 1977, 9, 97.

32 J. Troe, J. Chem. Phys., 1977, 66, 4758.

33 M. K. Dubey, R. Mohrschladt, N. M. Donahue and J. G. Anderson, J. Phys. Chem. A, 1997, 101, 1494.

34 T. H. Dunning Jr, J. Chem. Phys., 1989, 90, 1007.

35 NIST-JANAF Thermochemical Tables, ed. M. W. Chase, Jr., American Chemical Society and the American Institute of Physics, Woodbury, NY, 1998.

36 M. J. Frisch, G. W. Trucks, H. B. Schlegel, G. E. Scuseria, M. A. Robb, J. R. Cheeseman, J. J. A. Montgomery, T. Vreven, K. N. Kudin, J. C. Burant, J. M. Millam, S. S. Iyengar, J. Tomasi, V. Barone, B. Mennucci, M. Cossi, G. Scalmani, N. Rega, G. A. Petersson, H. Nakatsuji, M. Hada, M. Ehara, K. Toyota, R. Fukuda, J. Hasegawa, M. Ishida, T. Nakajima, Y. Honda,
O. Kitao, H. Nakai, M. Klene, X. Li, J. E. Knox, H. P. Hratchian, J. B. Cross, C. Adamo, J. Jaramillo, R. Gomperts, R. E. Stratmann, O. Yazyev, A. J. Austin, R. Cammi, C. Pomelli, J. W. Ochterski, P. Y. Ayala, K. Morokuma, G. A. Voth, P. Salvador, J. J. Dannenberg, V. G. Zakrzewski, S. Dapprich, A. D. Daniels, M. C. Strain, O. Farkas, D. K. Malick, A. D. Rabuck, K. Raghavachari, J. B. Foresman, J. V. Ortiz, Q. Cui, A. G. Baboul, S. Clifford, J. Cioslowski, B. B. Stefanov, G. Liu, A. Liashenko, P. Piskorz, I. Komaromi, R. L. Martin, D. J. Fox, T. Keith, M. A. Al-Laham, C. Y. Peng, A. Nanayakkara, M. Challacombe, P. M. W. Gill, B. Johnson, W. Chen, M. W. Wong, C. Gonzalez and J. A. Pople, GAUSSIAN 03, Gaussian, Wallingford, CT, version C.02, 2004.

37 R. A. Kendall, T. H. Dunning, Jr and R. J. Harrison, J. Chem. Phys., 1992, 96, 6796.

38 H.-J. Werner, P. J. Knowles, R. Lindh, M. Schütz, P. Celani, T. Korona, F. R. Manby, G. Rauhut, R. D. Amos, A. Bernhardsson, A. Berning, D. L. Cooper, M. J. O. Deegan, A. J. Dobbyn, F. Eckert, C. Hampel, G. Hetzer, A. W. Lloyd, S. J. McNicholas, W. Meyer, M. E. Mura, A. Nicklaß, P. Palmieri, R. Pitzer, U. Schumann, H. Stoll, A. J. Stone, R. Tarroni and T. Thorsteinsson, Molpro Quantum Chemistry Package, Birmingham, UK, version 2002.6, 2003

39 T. J. Lee and P. R. Taylor, Int. J. Quantum Chem., 1989, S23, 199.

40 J. M. L. Martin, in Computational Thermochemistry, ed. K. K. Irikura and D. J. Frurip, American Chemical Society, Washington, DC, 1998, American Chemical Society Symp. Ser. 677, ch. 12.

41 (a) A. C. Legon, D. J. Millen and H. M. North, Chem. Phys. Lett., 1987, 135, 303; (b) A. C. Legon and D. J. Millen, Chem. Soc. Rev., 1992, 21, 71.

42 (a) M. D. Marshall, B. V. Pond and M. I. Lester, J. Chem. Phys., 2003, 118, 1196; (b) B. V. Pond and M. I. Lester, J. Chem. Phys., 2003, 118, 2223.

43 I. B. Pollack, M. Tsiouris, H. O. Leung and M. I. Lester, J. Chem. Phys., 2003, 119, 118.

44 J. B. Davey, M. E. Greenslade, M. D. Marshall, M. I. Lester and M. D. Wheeler, J. Chem. Phys., 2004, 121, 3009. 